\title{
A Novel Mechanism of Dendritic Spine Plasticity Involving Estradiol Induction of Prostaglandin- $\mathrm{E}_{2}$
}

\author{
Stuart K. Amateau ${ }^{1}$ and Margaret M. McCarthy ${ }^{1,2}$ \\ ${ }^{1}$ Program in Neuroscience and ${ }^{2}$ Department of Physiology, University of Maryland at Baltimore, School of Medicine, \\ Baltimore, Maryland 21201
}

\begin{abstract}
The mechanisms establishing and maintaining dendritic spines in the mammalian CNS remain primarily unknown. We report a novel mechanism of neuronal spine plasticity in the developing preoptic area in which estradiol induces prostaglandin- $E_{2}$ $\left(\mathrm{PGE}_{2}\right)$ synthesis that in turn increases the density of spine-like processes. Estradiol requires $\mathrm{PGE}_{2}$ synthesis, in vivo and in vitro, and upregulates the dendritic spine protein spinophilin, an effect attenuated by antagonism of the AMPA-kainate receptor.
\end{abstract}

This signaling pathway may involve cross talk between neighboring neurons and astrocytes and appears specific to the preoptic area in that hippocampal neurons responded with an increase in spinophilin to estradiol but not $\mathrm{PGE}_{2}$. Regionally specific mechanisms of estradiol-mediated synaptic plasticity allow for epigenetic control of complex sex-typic behaviors.

Key words: estrogen; prostaglandin- $E_{2}$; dendritic spines; preoptic area; astrocytes; cyclooxygenase-2
A primary locus of excitatory synaptic transmission in the mammalian CNS is the dendritic spine (Colonnier, 1968; Larkman, 1991; Sorra and Harris, 2000). These protrusions from dendritic shafts exhibit dynamic changes in number, size, and shape in response to variation in hormonal status, developmental stage, and changes in afferent input (Fifkova, 1985; Munoz-Cueto et al., 1991; Woolley and McEwen, 1992; Moser et al., 1994; Murphy and Segal, 1996; McEwen and Alves, 1999). Understanding the mechanisms determining the formation and plasticity of dendritic spines remains a major goal of neuroscience.

Estradiol $\left(\mathrm{E}_{2}\right)$ has proven a potent regulator of dendritic spines and synapses in several discrete loci within the developing and adult brain. Exposure to $\mathrm{E}_{2}$ during a critical developmental period orchestrates permanent sexually dimorphic synaptic patterning in regions of the hypothalamus (Matsumoto and Arai, 1980, 1986; Matsumoto et al., 1988; Perez et al., 1990; Pozzo Miller and Aoki, 1991), whereas postpubertal $\mathrm{E}_{2}$ exposure controls dynamic changes in spine density in the hippocampus (Woolley et al., 1990; Woolley and McEwen, 1992; Woolley, 1998) and hypothalamus (Calizo and Flanagan-Cato, 2000). Elucidating the cellular and molecular mechanisms underlying $\mathrm{E}_{2}$ regulation of dendritic spine density provides a valuable model for establishing a relationship between modifications in synaptic patterning and complex behaviors.

Estradiol increases the level of prostaglandin- $\mathrm{E}_{2}\left(\mathrm{PGE}_{2}\right)$ in such diverse tissues as kidney and brain (Katayama and Lee, 1985; Ma et al., 1997). Elevated $\mathrm{PGE}_{2}$ is positively correlated with inflammatory pain responses (Ito et al., 2001), induction of neuronal apoptosis after ischemic injury (Takadera et al., 2002), and

Received April 4, 2002; revised May 30, 2002; accepted July 5, 2002.

This work was supported by a predoctoral National Research Service Award (MH12862) to S.K.A. and a grant from the National Institutes of Mental Health (MH52716) to M.M.M. We thank J. J. Alt for his critical and conscientious technical assistance with culture preparation as well as A. Z. Murphy, S. M. Thompson, A. Keller, and D. Weinreich for their constructive comments on this manuscript.

Correspondence should be addressed to Stuart K. Amateau, Program in Neuroscience, University of Maryland at Baltimore, School of Medicine, 655 West Baltimore Street, BRB 5020, Baltimore, MD 21201. E-mail: samat001@umaryland.edu. Copyright (C) 2002 Society for Neuroscience $0270-6474 / 02 / 228586-11 \$ 15.00 / 0$ increased tumorigenic and metastatic potential in estrogendependent breast cancers (Karmali et al., 1983; Kundu et al., 2001). The synthesis of prostanoids begins with the oxygenative cyclization of arachidonic acid by cyclooxygenase. The inducible isoform of cyclooxygenase, cyclooxygenase-2 (COX-2), is an immediate early gene enriched within dendritic spines and postulated to play a role in synaptic plasticity (Kaufmann et al., 1997). Cyclooxygenase-2 expression is strongly regulated during normal postnatal development in the rat, following well known histiogenetic gradients and coinciding with the critical period for activitydependent synaptic remodeling (Kaufmann et al., 1996). Of the prostanoids synthesized by $\mathrm{COX}-2, \mathrm{PGE}_{2}$ is one of the most biologically active of the family and has long been recognized as a diffusible factor capable of regulating several second messenger pathways in a variety of tissues (Villani et al., 1974; Luczak et al., 1979; Ruwe and Myers, 1979).

Astrocytes are important in synapse formation and efficacy (Pfrieger and Barres, 1997; Ullian et al., 2001), including that of $\mathrm{E}_{2}$-induced dendritic spine synapses (Mong et al., 1999, 2001). Recent and emerging evidence implicates $\mathrm{PGE}_{2}$ as a mediator of dynamic cell-to-cell communication involving cross talk between astrocytes and neurons (Ma et al., 1997; Rage et al., 1997; Bezzi et al., 1998; Sanzgiri et al., 1999). Astrocyte-to-neuron signaling regulates the number of dendritic spines available for synaptogenesis in regions of the developing brain (Baloyannis and Kim, 1979; Meshul and Seil, 1988; Seil et al., 1992; Seil, 1997). Astrocytes release glutamate in response to $\mathrm{PGE}_{2}$ (Nicol et al., 1992; Bezzi et al., 1998), which can activate the glutamate receptors of neighboring neurons and modulate their dendritic spine density (McKinney et al., 1999a,b; Luthi et al., 2001). A relationship between $\mathrm{PGE}_{2}$ and neuronal morphology, however, has not previously been demonstrated. We report here a novel role for $\mathrm{PGE}_{2}$ in synaptic plasticity, the induction of dendritic spines in response to the gonadal steroid $\mathrm{E}_{2}$. This effect is region specific in that it is observed in the preoptic area (POA) but not the hippocampus, and it is dependent on the activation of AMPA-kainate receptors by glutamate that may originate from astrocytes. 

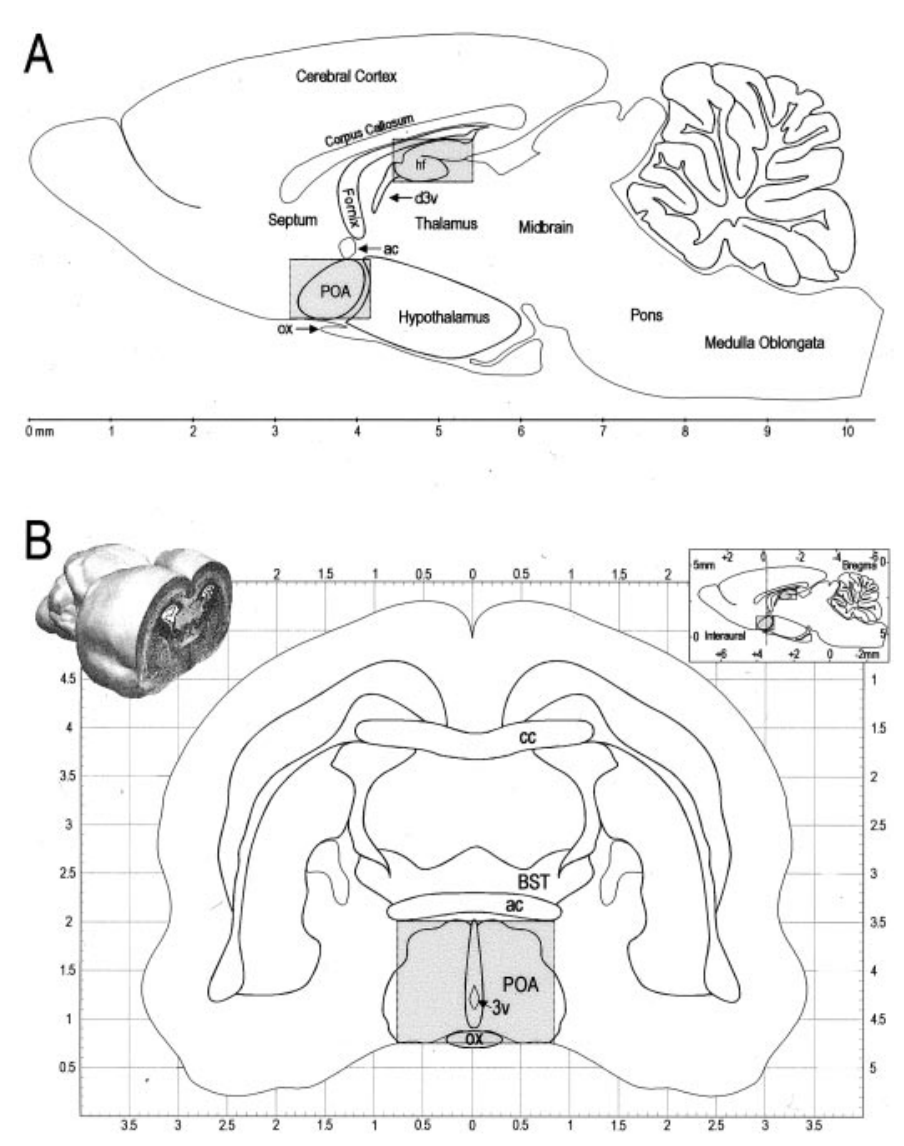

Figure 1. Microdissection of the preoptic area and the rostral hippocampal formation. $A$, Sagittal drawing of the developing rat brain demonstrating the areas collected (shaded regions) and the landmarks used to guide the microdissection, including the anterior commissure $(a c)$ and the optic chiasm (ox) for the preoptic area $(P O A)$, and the corpus callosum and the dorsal portion of the third ventricle $(d 3 v)$ for the hippocampal formation (hf). B, Coronal drawing of the neonatal brain at the level of the POA. Top left, Three-dimensional reconstruction of the neonatal brain at the level of the section (taken from Altman and Bayer, 1995). Top right, Sagittal view of the neonatal brain displaying the rostral to caudal coordinates used for collecting the POA. Shaded region represents the area collected for microdissections that were guided by the anterior commissure and the optic chiasm. $c c$, Corpus callosum; BST, bed nucleus of the stria terminalis; $3 v$, third ventricle. Grid scale, $0.5 \mathrm{~mm}$.

\section{MATERIALS AND METHODS}

Animals. Female Sprague Dawley rats (Charles River Laboratories, Wilmington, MA) were mated in our animal facility, and pregnancy was confirmed by vaginal smear. Pregnant females were isolated and allowed to deliver normally. Animals were maintained on a reverse $12 \mathrm{hr}$ light/ dark cycle and provided ad libitum access to food and water. Cages were checked regularly for the presence of pups to determine the day of birth [postnatal day $0(\mathrm{P} 0)$ ], and litters that were found the morning of delivery were used for experiments. Female pups were used for experiments involving hormonal manipulation to avoid the endogenous hormonal exposure that occurs in males.

Microdissection and culture conditions. Under sterile conditions, brains were removed within 1-2 hr after birth, placed in a Zivic Miller brain mold, and sectioned at $1 \mathrm{~mm}$. The POA and rostral hippocampal formation (including the rostral portions of the differentiating CA1 and CA3 fields as well as the dentate gyrus) were microdissected using the guidelines illustrated in Figure 1, $A$ and $B$. Briefly, the optic chiasm appears near the rostral portion of the diencephalon and was used as a landmark to guide the rostral-to-caudal dissection within the brain mold. The POA was then microdissected from the 1 -mm-thick section using the perimeter of the anterior commissure for both the dorsal and lateral incisions (Fig. $1 B)$. Another $1 \mathrm{~mm}$ slice was taken immediately posterior to the section containing the POA. This segment contained the rostral portion of the hippocampal formation, which was microdissected using the lateral ventricle to delineate the lateral limits, the corpus callosum, the dorsal limit, and the dorsal portion of the third ventricle the ventral limit (Fig. $1 \mathrm{~A}$ ). Tissue chunks were placed in HBSS + [HBSS, HEPES buffer, antibiotic/ antimycotic $(10,000 \mathrm{U}$ of penicillin G sodium, 10,000 $\mu \mathrm{g}$ of streptomycin sulfate, and $25 \mu \mathrm{g}$ of Amphotericin B)] (Invitrogen, Grand Island, NY) and $0.25 \%$ trypsin. After $15 \mathrm{~min}$ at $37^{\circ} \mathrm{C}, 1 \mathrm{ml}$ of $10 \%$ dextran-treated charcoal-stripped fetal bovine serum (Invitrogen) and $0.5 \mathrm{ml}$ of antibiotic/antimycotic (FBS+) was added to deactivate the trypsin. The solution was dissociated by mechanical triturating and centrifuged at 1000 rpm for $5 \mathrm{~min}$, the supernatant was discarded, and the pellet was resuspended in phenol red-free, sterile culture medium (SCM) [DMEMF12 (Invitrogen) and FBS+]. Density was established, and cells were seeded onto poly-L-lysine (MW 70,000; Sigma, St. Louis, MO)-coated glass coverslips (number 1, $25 \mathrm{~mm}$ diameter; Fisher Scientific, Pittsburgh, PA) at a density of 150,000 . Plates were maintained in an incubator at $37^{\circ} \mathrm{C}$ and $5 \% \mathrm{CO}_{2}$ for $4 \mathrm{~d}$ in vitro (DIV; time of plating, DIV0). Cells were allowed to acclimate for $24 \mathrm{hr}$ before first treatment and were treated on DIV1 and DIV2 and collected in lysis buffer on DIV3 for Western analysis, $\sim 24 \mathrm{hr}$ after the second treatment. Treatments were added to existing culture medium, and depending on the specific experiment, cells were exposed to the following either individually or in combination: (1) sesame oil vehicle, (2) $0.5 \mathrm{nM} \mathrm{PGE}_{2}$ in $0.9 \%$ saline, (3) $0.5 \mathrm{nM} \mathrm{PGF}_{2 \alpha}$ in $0.9 \%$ saline, (4) $5 \mathrm{~nm}$ estradiol benzoate $\left(\mathrm{E}_{2}\right)$ in $0.001 \%$ DMSO in sesame oil, (5) $1 \mu \mathrm{M}$ indomethacin in sesame oil, (6) $10 \mu \mathrm{M}$ L-glutamic acid in $0.9 \%$ saline, (7) $40 \mu \mathrm{M}(+)$-M K801 in $0.9 \%$ saline, (8) $100 \mu \mathrm{M}$ DL-AP-5 in $0.9 \%$ saline, and (9) $40 \mu \mathrm{M}$ DNQX in $0.9 \%$ saline ( $n=6 /$ group for all culture experiments). Doses of the $\mathrm{PGE}_{2}$ and estradiol were based on published literature (Whalen and Nadler, 1963; Morimoto et al., 1991; Mouihate and Lestage, 1995; Caggiano and Kraig, 1998; Southall and Vasko, 2000) as well as our own experience (Mong et al., 1999). Doses of estradiol were $5 \mathrm{~nm}$ in vitro and $100 \mu \mathrm{g}$ in vivo. This seemingly large in vivo dose was used to overwhelm $\alpha$-fetoprotein, an endogenous steroid-binding globulin found in the fetal circulation. This protein binds estradiol, preventing the hormone from crossing the bloodbrain barrier and from entering cells, thereby protecting the female fetuses from being masculinized by estradiol originating in the dam. Levels of $\alpha$-fetoprotein reach a maximum during the same perinatal period that testosterone surges and remain at significant levels in the bloodstream of pups for several days after birth (Montano et al., 1995).

Immunocytochemistry: microtubule-associated protein-2 and spinophilin immunoreactivity. Coverslips with adhered cells were immersed in $4 \%$

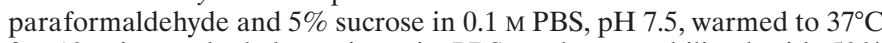
for $10 \mathrm{~min}$, washed three times in PBS, and permeabilized with $50 \%$ ethanol for $60 \mathrm{~min}$ at $4^{\circ} \mathrm{C}$. The cells were then washed three times in PBS and incubated in $10 \%$ normal goat serum in $0.4 \%$ Triton X-100 PBS (PBST) for $60 \mathrm{~min}$ at room temperature with agitation. After blocking, either a mouse monoclonal anti-microtubule-associated protein-2 (MAP-2) primary antibody (Sigma) (1:3000) or a rabbit polyclonal anti-spinophilin/neurabin II primary antibody (Upstate Biotechnology, Lake Placid, NY) (1:8000) was applied in 10\% normal goat serum PBST, and the cultures were incubated overnight at $4^{\circ} \mathrm{C}$. The coverslips were washed three times in PBST and incubated in biotinylated secondary antibody (1:500; goat anti-mouse or goat anti-rabbit; Vector Laboratories, Burlingame, CA) for $60 \mathrm{~min}$ at room temperature with agitation, followed by three washes in PBST. The cultures were then incubated with an avidin-biotin horseradish-peroxidase complex (Vectastain ABC, Elite Kit; Vector Laboratories) for $60 \mathrm{~min}$ at room temperature, washed twice with PBST, and visualized with $0.05 \%$ 3,3'-diaminobenzidine tertrahydrochloride (Polysciences, Warrington, PA) and $0.005 \% \mathrm{H}_{2} \mathrm{O}_{2}$. After visualization, the coverslips were mounted on $2 \%$ gelatin-coated glass slides.

In vivo hormonal manipulations and comparison of spinophilin levels between sexes. Female pups received two hormonal treatments $24 \mathrm{hr}$ apart with the first within $6 \mathrm{hr}$ of birth. Animals were assigned to one of six treatment regiments including: (1) subcutaneous injections of $0.1 \mathrm{cc}$ sesame oil, (2) subcutaneous injections of $100 \mu \mathrm{g}$ of $\mathrm{E}_{2}$ in $0.1 \mathrm{cc}$ sesame oil, (3) subcutaneous injections of $25 \mu \mathrm{g}$ of indomethacin and $100 \mu \mathrm{g}$ of $\mathrm{E}_{2}$ in $0.1 \mathrm{cc}$ sesame oil, (4) intracerebroventricular injections of $2 \mu \mathrm{g}$ of $\mathrm{PGE}_{2}$ in $0.1 \mathrm{cc}$ of $0.9 \%$ saline and subcutaneous injections of $0.1 \mathrm{cc}$ oil, (5) intracerebroventricular injections of $2 \mu \mathrm{g}$ of $\mathrm{PGE}_{2}$ in $0.1 \mathrm{cc}$ of $0.9 \%$ saline and subcutaneous injections of $25 \mu \mathrm{g}$ indomethacin in $0.1 \mathrm{cc}$ sesame oil, or (6) intracerebroventricular injections of $0.9 \%$ saline and subcutaneous injections of $0.1 \mathrm{cc}$ sesame oil ( $n=4$ /group). Intracerebro- 
ventricular injections were performed by hand on cold-anesthetized pups. Under bright light, the cranial landmark Bregma is visible through the skin and was used to locate the lateral ventricles. Injections were performed by penetrating the skin and skull with a 23 gauge $1 \mathrm{cc}$ Hamilton syringe stereotaxically lowered to a predetermined depth. Infusion volume was $0.1 \mathrm{cc}$ and extended for a $60 \mathrm{sec}$ period. Brains were collected on $\mathrm{P} 2, \sim 24 \mathrm{hr}$ after the second treatment. To determine the levels of spinophilin within the POA on the day of birth, POA tissue was collected within $2 \mathrm{hr}$ of birth from male $(n=5)$ and female $(n=5)$ littermates and immediately flash frozen in isopentane and stored at $-70^{\circ} \mathrm{C}$.

Western immunoblots. For cultured cells, coverslips were rinsed with $250 \mu \mathrm{l}$ of TBS and then immersed in $75 \mu \mathrm{l}$ of lysis buffer, $\mathrm{pH} 7.5$, consisting of $0.8 \%$ Tris- $\mathrm{HCl}, 0.9 \% \mathrm{NaCl}, 1 \%$ Tergitol NP-40 (Sigma), 1 $\mathrm{mm}$ phenylmethylsulfonyl fluoride, and peptidases including leupeptin, aprotinin, and pepstatin $(1 \mu \mathrm{g} / \mathrm{ml})$ for $5 \mathrm{~min}$ at $4^{\circ} \mathrm{C}$. The coverslips were grazed with a cell scraper, and the resulting homogenate was collected. For analysis of in vivo brain tissue, the POA and rostral hippocampal formation were microdissected as described above, flash frozen in isopentane, and stored at $-70^{\circ} \mathrm{C}$ until being homogenized in lysis buffer as described above with $0.5 \%$ Triton X-100 (Sigma) substituting for NP-40. The homogenate was then subjected to a Bradford protein assay to determine and standardize protein levels in subsequent Western analyses. Protein $(10 \mu \mathrm{g})$ was electrophoresed in separate lanes on an $8-16 \%$ precast SDS-polyacrylamide gel (Novex, San Diego, CA) and transferred to a polyvinyl difluoride membrane (Bio-Rad, Hercules, CA). Membranes were blocked in $5 \%$ nonfat milk in $0.1 \%$ Tween TBS (M-TTBS) for $1 \mathrm{hr}$ at room temperature and then incubated in anti-spinophilin/ neurabin II rabbit polyclonal IgG (Upstate Biotechnology) at $1 \mu \mathrm{g} / \mathrm{ml}$ in M-TTBS. A 30 min incubation of a goat anti-rabbit HRP (New England BioLabs, Beverly, MA) conjugated IgG at a 1:10,000 dilution followed. The Phototope chemiluminescence system (New England BioLabs) was used for detection of the protein recognized by the antisera. The blots were exposed on Hyperfilm-ECL (Amersham, Arlington Heights, IL) for varying exposure times $(30-60 \mathrm{sec})$. The protein was detected as a band of relative molecular mass of $120 \mathrm{kDa}$, and the integrative grayscale pixel area-density (iad) was captured with a CCD camera and quantified using NIH Image software.

Reverse transcription-PCR. Brains were removed and placed in a Zivic Miller brain mold and immediately sectioned at $1 \mathrm{~mm}$. The POA was microdissected as described above, flash frozen in isopentane, and stored at $-70^{\circ} \mathrm{C}$ until being homogenized. Tissue from the kidney was also collected to verify the detection of EP4. Tissue was used for isolation of total RNA using an RNeasy Mini Kit (Qiagen, Valencia, CA). RNA concentration was determined by spectrophotometery, and $1 \mu \mathrm{g}$ of RNA was reverse translated to DNA and then amplified using the one step protocol for Ready-To-Go RT-PCR beads (Amersham Pharmacia Biotech, Buckinghamshire, UK). DEPC-treated water and $20 \mathrm{pmol}$ of each primer was added to the RNA and RT-PCR bead at $4^{\circ} \mathrm{C}$. This solution was transferred to the thermal cycler and cycled 35 times at annealing temperatures appropriate for each primer pair $\left(55-62^{\circ} \mathrm{C}\right)$. All oligonucleotides used were synthesized by Invitrogen (Rockville, MD) with standard purity. Subsequent PCR product was electrophoresed on a $2 \%$ agarose gel in Tris-acetate, and DNA product was visualized with chelation of $0.5 \%$ ethidium bromide.

Gas chromatography-mass spectrometry. Female pups received two treatments $24 \mathrm{hr}$ apart with the first within $6 \mathrm{hr}$ of birth. Females were assigned to one of two regimes: two subcutaneous injections of $0.1 \mathrm{cc}$ sesame oil $(n=5)$ or two subcutaneous injections of $100 \mu \mathrm{g}$ of $\mathrm{E}_{2}$ in 0.1 cc sesame oil $(n=6)$. The POA was collected and immediately prepared for mass spectrophotometery $12 \mathrm{hr}$ after the second treatment. Briefly, each sample, consisting of $\sim 30 \mathrm{mg}$ of tissue, was rinsed with HBSS (containing $138 \mathrm{~nm} \mathrm{NaCl}, 5 \mathrm{~mm} \mathrm{KCl}, 4 \mathrm{~mm} \mathrm{NaHCO} 3,5.6 \mathrm{~mm}$ D-glucose,

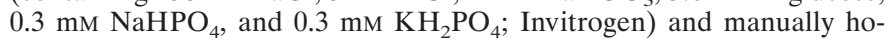
mogenized in a glass-microhomogenizer with $75 \mu \mathrm{l}$ of HBSS containing $1 \mathrm{mM} \mathrm{CaCl}_{2}$. An additional $75 \mu \mathrm{l}$ of HBSS was added, and the solution was sonicated for $20 \mathrm{sec}$. Any tissue debris was removed by centrifugation at 12,000 rpm for $15 \mathrm{sec}$. Ten microliters of the supernatant was used for Bradford protein assay. Fifty microliters of denatured prostanoid standards and $250 \mu \mathrm{l}$ of acetone were added, and the solution was vortexed and centrifuged for $5 \mathrm{~min}$. The supernatant was divided equally and dried under a steady stream of nitrogen gas. Once completely dry, 25 $\mu \mathrm{l}$ of $2 \% 0$-methoxylamine $\mathrm{HCl}$ in pyridine was added to each sample. The pyridine solvent evaporated under a nitrogen stream, and the residue in each vial was treated with reagents to synthesize the pentaflu- orobenzyl ester-trimethylsilyl ether derivatives of the prostanoids for gas chromatography-mass spectrometric (GC-MS) analysis at the Asthma and Allergy Center of Johns Hopkins University School of Medicine (Baltimore, MD). Levels of prostanoids were subsequently normalized to the amount of protein in each sample.

Data collection and analyses. Analysis of MAP-2 immunocytochemical cellular morphology was performed under a Nikon $100 \times$ oil-immersion objective using the Neurolucida system (MicroBrightField Inc., Colchester, VT). Ten neurons from six coverslips of each treatment $(n=$ 6/group) were examined. Criteria for cell selection included the ability of the experimenter to discern individual neurons stained evenly from soma to distal processes. Neurons entangled with one another were therefore excluded. Neurons were chosen from areas of even cell survival, thus neurons growing within dense or sparse pockets were also excluded. The experimenter was blind to the treatment group throughout analysis. The following morphological features were measured: somal area (in square micrometers), neurite length (in micrometers), neurite number, primary and secondary neurite branching, number of spine-like processes (per neurite), and density of spine-like processes (spine number per micrometer), with a spine defined as any protrusion $<5 \mu \mathrm{m}$. Analyses of the spine-like processes incorporated the complete neurite from soma to distal end and included all processes extending from each neuron examined. Typically a 1:2 ratio of neurons to astrocytes was observed in these 3-d-old cultures. Western blots were compared within each gel, with the exception of the in vitro spinophilin experiments where results were across several immunoblots with an $n$ value of two or four for each group within each blot. For these, bands were quantified as a ratio of iad with the iad of the DMSO controls of the same gel serving as the comparison group. This standardization allowed for the analysis of multiple groups (each with an $n=6$ ) across multiple films. For the comparison between sexes on the day of birth, males were compared with females on the same gel and represented in arbitrary units. All results except those of the GC-MS and sex dimorphism experiments were analyzed using a oneway ANOVA followed by the Student-Neumann-Keuls post hoc multiple comparison test to determine significance between groups. Results of the GC-MS were analyzed using Student's $t$ test between treatment groups, as were those of the sex dimorphism experiment, data from which were expressed in arbitrary units. All statistical tests used $\alpha<0.05$ as the criterion for significance.

GenBank accession numbers. The accession numbers for the sequences of the previously identified prostaglandin- $E_{2}$ receptor subtypes are as follows: EP1 (D88751); EP2 (U94708); EP3 (NM-012704); and EP4 (U94709).

\section{RESULTS}

\section{Estradiol or $\mathrm{PGE}_{2}$ increase spine-like processes in cultured POA neurons}

To explore the possible role of $\mathrm{E}_{2}$ in mediating changes in the morphology of neurons, POA tissue from newborn females was dispersed and plated. Cells acclimated for $24 \mathrm{hr}$ and were then exposed to physiologic levels of $\mathrm{E}_{2}(5 \mathrm{nM})$ for $48 \mathrm{hr}$ before postfixing and immunocytochemical detection of neuron-specific MAP-2. Cell morphology was assessed at the light level using the Neurolucida image analysis system. Estradiol-treated cultures showed an almost threefold increase in the mean number per neurite $\left(F_{(3,12)}=21.8 ; p<0.001\right)$, and in a separate experiment, density $\left(F_{(5,24)}=26.2 ; p<0.001\right)$ of spine-like processes, with a spine defined as any neurite protrusion $<5 \mu \mathrm{m}$ in length (Fig. 2A-D).

Spines were visualized by immunocytochemistry for MAP-2 using diaminobenzidine as the chromagen. Microtubule proteins, such as MAP-2, are localized to the dendritic shaft of hippocampal neurons and are associated with the relative stability of this structure as compared with the plasticity of dendritic spines (Kaech et al., 2001). Our ability to visualize spine-like processes on cultured POA neurons with MAP-2 immunocytochemistry may be a result of intracellular spread of the reaction product or may be functionally related to a process of spine induction different from that seen in hippocampus. Moreover, the plasticity of the dendritic architecture may vary between the two regions. 

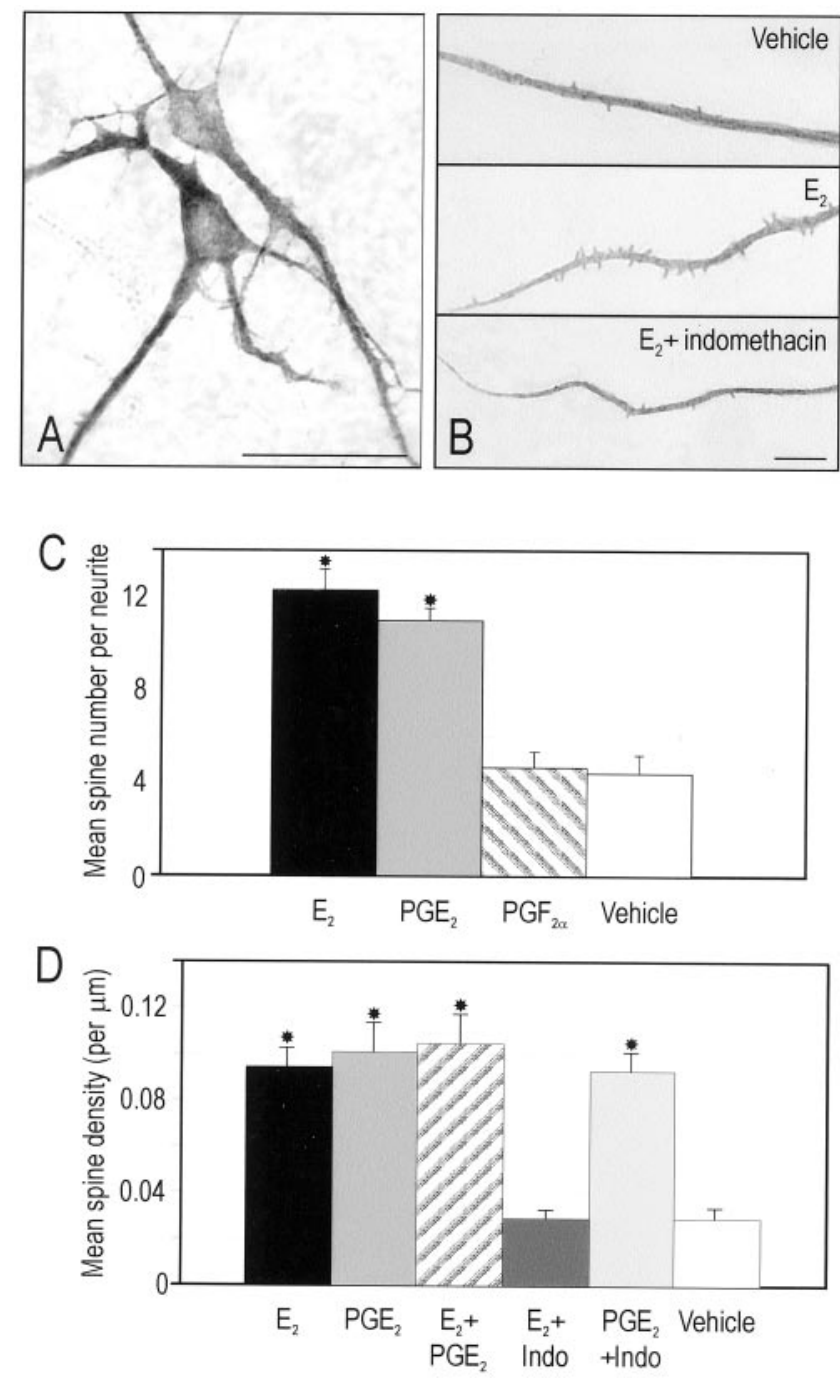

Figure 2. $\mathrm{E}_{2}$ or $\mathrm{PGE}_{2}$ increase spine-like processes of preoptic area neurons in vitro. $A$, Representative photomicrograph of cultured neurons treated with $0.5 \mathrm{~nm} \mathrm{PGE}$ on DIV1 and DIV2 and visualized on DIV3 after immunocytochemical detection of MAP-2. Numerous aspects of neuronal morphology were assessed, but the only changes observed were in the number and density of spine-like processes, defined as any protrusion $<5 \mu \mathrm{m}$ in length. Scale bar, $25 \mu \mathrm{m}$. B, Representative photomicrographs of the neurites of cultured neurons treated with vehicle, $5 \mathrm{nM} \mathrm{E}_{2}$, or $5 \mathrm{nM} \mathrm{E}_{2}$ coadministered with $1 \mu \mathrm{M}$ of the cyclooxygenase inhibitor indomethacin, and visualized after MAP-2 immunocytochemistry. Scale bar, $5 \mu \mathrm{m}$. $C$, Treatment with $\mathrm{E}_{2}(5 \mathrm{nM})$ or $\mathrm{PGE}_{2}(0.5 \mathrm{nM})$ for $48 \mathrm{hr}$ resulted in a significant increase in the number of spine-like processes on neurites. $\mathrm{PGF}_{2 \alpha}(0.5 \mathrm{nM})$ had no effect compared with vehicle-treated controls (10 neurons from each coverslip, $n=6$ per group, ANOVA; ${ }^{*} p<$ 0.001 compared with $\mathrm{PGF}_{2 \alpha}$ and vehicle). D, Similar effects of $\mathrm{E}_{2}$ and $\mathrm{PGE}_{2}$ were seen on mean spine density in a separate experiment. The combination of $\mathrm{E}_{2}$ and $\mathrm{PGE}_{2}$ was not different from either one alone. The induction of spine-like processes by $\mathrm{E}_{2}$ was blocked by simultaneous administration of indomethacin $(1 \mu \mathrm{M})$ but had no effect on the actions of exogenous $\mathrm{PGE}_{2}$ (10 neurons from each coverslip, $n=6$ per group, ANOVA; ${ }^{*} p<0.001$ compared with $\mathrm{E}_{2}+$ Indo and vehicle).

We next tested the hypothesis that $\mathrm{PGE}_{2}$ is a mediator of $\mathrm{E}_{2}$-induced spine induction. Treatment with $\mathrm{PGE}_{2}(0.5 \mathrm{nM})$ for 48 hr precisely mimicked the effect of $E_{2}$, causing a significant increase in both spine number per neurite $(p<0.001)$ and density $(p<0.001)$. $\mathrm{PGF}_{2 \alpha}$, a biologically active eicosanoid converted from the same immediate precursor as $\mathrm{PGE}_{2}$, had no effect on spine number. Simultaneous administration of the cyclooxygenase inhibitor, indomethacin $(1 \mu \mathrm{M})$, blocked the induction of spine-like processes by $E_{2}$ but had no effect on the actions of exogenous $\mathrm{PGE}_{2}\left(p<0.001\right.$ from vehicle and $\mathrm{E}_{2}$ and indomethacin). The combination of $\mathrm{E}_{2}$ and $\mathrm{PGE}_{2}$ was not significantly different from either one alone. There were also no significant differences between $\mathrm{E}_{2}$-treated and control cultures in somal size, neurite length, neurite number, or neurite branching. Similarly, the effects of $\mathrm{PGE}_{2}$ treatment were limited solely to changes in spines, with no other effects on neuronal morphology observed (data not shown).

\section{Estradiol or $\mathrm{PGE}_{2}$ increase spinophilin expression in cultured POA neurons}

Spinophilin, a protein highly enriched within dendritic spines, has been implicated in regulating spine formation and function (Allen et al., 1997; Feng et al., 2000). We therefore used it as a protein marker of spines (Fig. $3 A, B$ ), with the assumption that increases in spinophilin expression would result in proportional increases in spine density. POA cell cultures were treated as above, the cells collected and protein levels analyzed by Western blot. Consistent with our morphological analysis, both $\mathrm{E}_{2}$ or $\mathrm{PGE}_{2}$ induced a threefold increase in spinophilin expression $\left(F_{(6,35)}=66.9 ; p<0.001\right)$. Indomethacin again blocked the effect of $\mathrm{E}_{2}$ but did not alter the effect of exogenous $\mathrm{PGE}_{2}$. As with spine-like processes, the combination of $\mathrm{E}_{2}$ and $\mathrm{PGE}_{2}$ did not increase spinophilin expression above that seen with either treatment alone (Fig. 3C,D). Although there was a striking similarity in the magnitude and direction of treatment effects on spinophilin levels detected by Western blot and spine-like processes detected by MAP-2 immunocytochemistry, a direct relationship between these two variables has not been established.

\section{Antagonism of the AMPA-kainate receptor reduces both $E_{2}$ - and $P G E_{2}$-induced spinophilin expression}

Localization of ionotropic glutamate receptors to dendritic compartments allows for selective regulation of spine formation by glutamate released from axonal growth cones, presynaptic terminals, and neighboring astrocytes (Mattson, 1988; Goldin et al., 2001). Expression of glutamate receptors peaks during a developmental time window within which synaptogenesis occurs (Tremblay et al., 1988; Herrmann, 1996; Zhang et al., 1996). We therefore tested the hypothesis that ionotropic glutamate receptor activation participates in the estradiol-mediated increases in spinophilin. Effects of glutamate $(10 \mu \mathrm{M})$ exposure paralleled those of $\mathrm{E}_{2}$ and $\mathrm{PGE}_{2}$, demonstrating a threefold increase in spinophilin expression $\left(F_{(3,18)}=113.8 ; p<0.001\right)$ in POA cell cultures (Fig. 4A,B). The selective AMPA-kainate antagonist DNQX $(40 \mu \mathrm{M})$ attenuated estradiol-mediated increases in spinophilin expression by $56.6 \%$ and $\mathrm{PGE}_{2}$-mediated increases by $66.2 \%\left(F_{(4,23)}=106.5 ; p<0.001\right)$, establishing the role of glutamate subsequent to that of $\mathrm{E}_{2}$ and the prostanoid (Fig. $4 C$ ). Both the noncompetitive NMDA antagonist (+)-MK801 (40 $\mu \mathrm{M})$ and the selective NMDA antagonist DL-AP-5 (100 $\mu \mathrm{M})$ had no effect on induction of spinophilin by estradiol. Application of the any of the antagonists alone had no effect on baseline spinophilin expression (data not shown), further supporting an active role for $\mathrm{E}_{2}$ in the induction of $\mathrm{PGE}_{2}$ synthesis and subsequent glutamate release. 

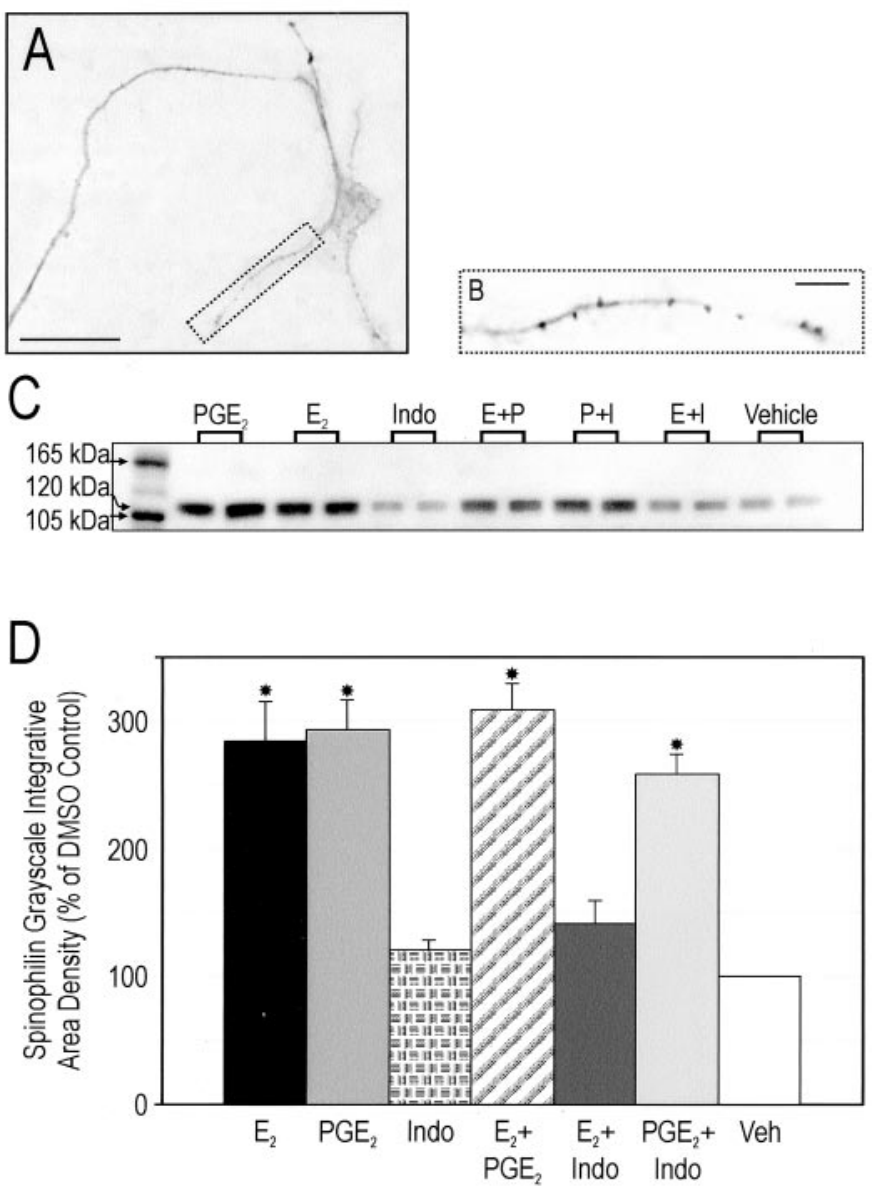

Figure 3. $\mathrm{E}_{2}$ or $\mathrm{PGE}_{2}$ increase expression of spinophilin protein in the preoptic area in vitro. A, Representative photomicrograph of the neurites of cultured neurons treated with $5 \mathrm{nM} \mathrm{E}_{2}$ and visualized after spinophilin immunocytochemistry. Scale bar, $25 \mu \mathrm{m}$. B, Enlargement of process encapsulated in $A$. Each punctum corresponds to one locus of concentrated protein. Scale bar, $5 \mu \mathrm{m}$. $C$, Representative Western immunoblot from treated cultures loaded onto each lane $3 \mathrm{~d}$ after plating. Cultures were exposed to the following either individually or in combination for 48 hr: (1) $0.5 \mathrm{nM} \mathrm{PGE}_{2}$, (2) $5 \mathrm{~nm} \mathrm{E}_{2}$, (3) $1 \mu \mathrm{M}$ indomethacin, or (4) vehicle. The blot was probed with an anti-spinophilin/neurabin II rabbit polyclonal antibody that recognized an appropriate band at $120 \mathrm{kDa}$. $D$, Analysis of Western immunoblots of cultured newborn preoptic area neurons treated for $48 \mathrm{hr}$ in vitro. Data represent a ratio of iad with the iad of the vehicle controls of the same gel serving as the comparison group ( $n=6$ per group). This standardization allowed for the analysis of seven groups across three gels. Treatment with $\mathrm{E}_{2}$ or $\mathrm{PGE}_{2}$ resulted in a significant increase in expression of spinophilin. Coadministration of both did not augment effects seen when applied individually. Indomethacin blocked the estradiol-induced effect on spinophilin expression and had no effect alone (ANOVA; ${ }^{*} p<0.001$ compared with Indo, $\mathrm{E}_{2}+$ Indo, or vehicle).

\section{Prostaglandin receptor mRNA is expressed in the developing POA}

For prostaglandins to promote dendritic spine formation early in development, the cognate receptors must be expressed perinatally. RT-PCR was used to identify the population of prostaglandin receptors (EP) expressed in the POA on the day of birth and amplified the mRNA of three of the four subtypes, EP1, EP2, and EP3 (Fig. 5A). EP4 mRNA was not detected in the POA, but was amplified in kidney as a positive control.
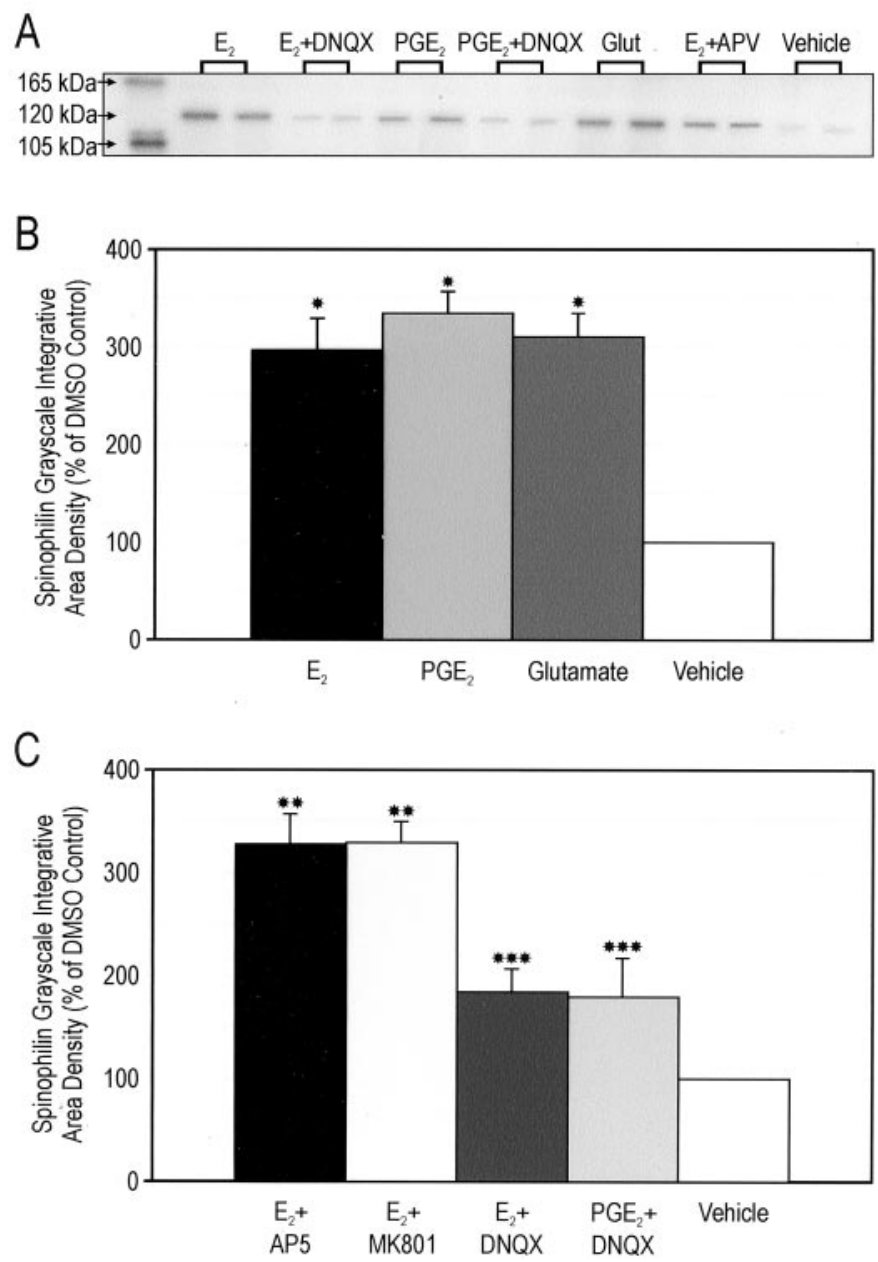

Figure 4. Antagonism of the AMPA-kainate receptor attenuates $\mathrm{E}_{2}$ - or $\mathrm{PGE}_{2}$-induced spinophilin expression. $A$, Representative Western immunoblot from treated POA cultures $3 \mathrm{~d}$ after plating. Cultures were exposed to the following either individually or in combination for $48 \mathrm{hr}$ : (1) $0.5 \mathrm{nM}$ $\mathrm{PGE}_{2}$, (2) $5 \mathrm{nM} \mathrm{E} \mathrm{e}_{2}$, (3) $10 \mu \mathrm{M}$ glutamate, (4) $100 \mu \mathrm{M}$ AP-5, (5) $40 \mu \mathrm{M}$ MK801, (6) $40 \mu \mathrm{M}$ DNQX, or (7) vehicle. The blot was probed with an anti-spinophilin/neurabin II rabbit polyclonal antibody that recognized an appropriate band at $120 \mathrm{kDa}$. $B, C$, Analysis of Western immunoblots of cultured newborn preoptic area neurons treated for $48 \mathrm{hr}$ in vitro. Data represent a ratio of iad with the iad of the vehicle controls of the same gel serving as the comparison group ( $n=6$ per group). Treatment with glutamate resulted in an increase in the expression of spinophilin comparable with that induced by either $\mathrm{E}_{2}$ or $\mathrm{PGE}_{2}$. Coadministration of the AMPA-kainate antagonist DNQX significantly reduced both the $\mathrm{E}_{2}$ and $\mathrm{PGE}_{2}$-induced increase in expression, whereas coapplication of NMDA receptor antagonists had no effect on expression (ANOVA; ${ }^{*} p<0.001$ compared with vehicle; $* * p<0.001$ compared with $\mathrm{E}_{2}+$ DNQX, $\mathrm{PGE}_{2}$ + DNQX, and vehicle; ***p $<0.001$ compared with $\mathrm{E}_{2}+\mathrm{AP}-5, \mathrm{E}_{2}+$ MK801, and vehicle).

\section{Estradiol or $\mathrm{PGE}_{2}$ increase spinophilin expression in vivo in the POA}

We next asked whether $\mathrm{PGE}_{2}$ is required for the induction of dendritic spines by $\mathrm{E}_{2}$ in the POA in vivo. Newborn female rat pups received subcutaneous injections of $\mathrm{E}_{2}(100 \mu \mathrm{g})$ or intracerebroventricular infusions of $\mathrm{PGE}_{2}(2 \mu \mathrm{g})$. Forty-eight hours later, the brains were collected, and the POA was rapidly dissected and flash frozen until assay by Western blot. The expression of spinophilin was significantly increased after $\mathrm{E}_{2}\left(F_{(2,9)}=\right.$ 

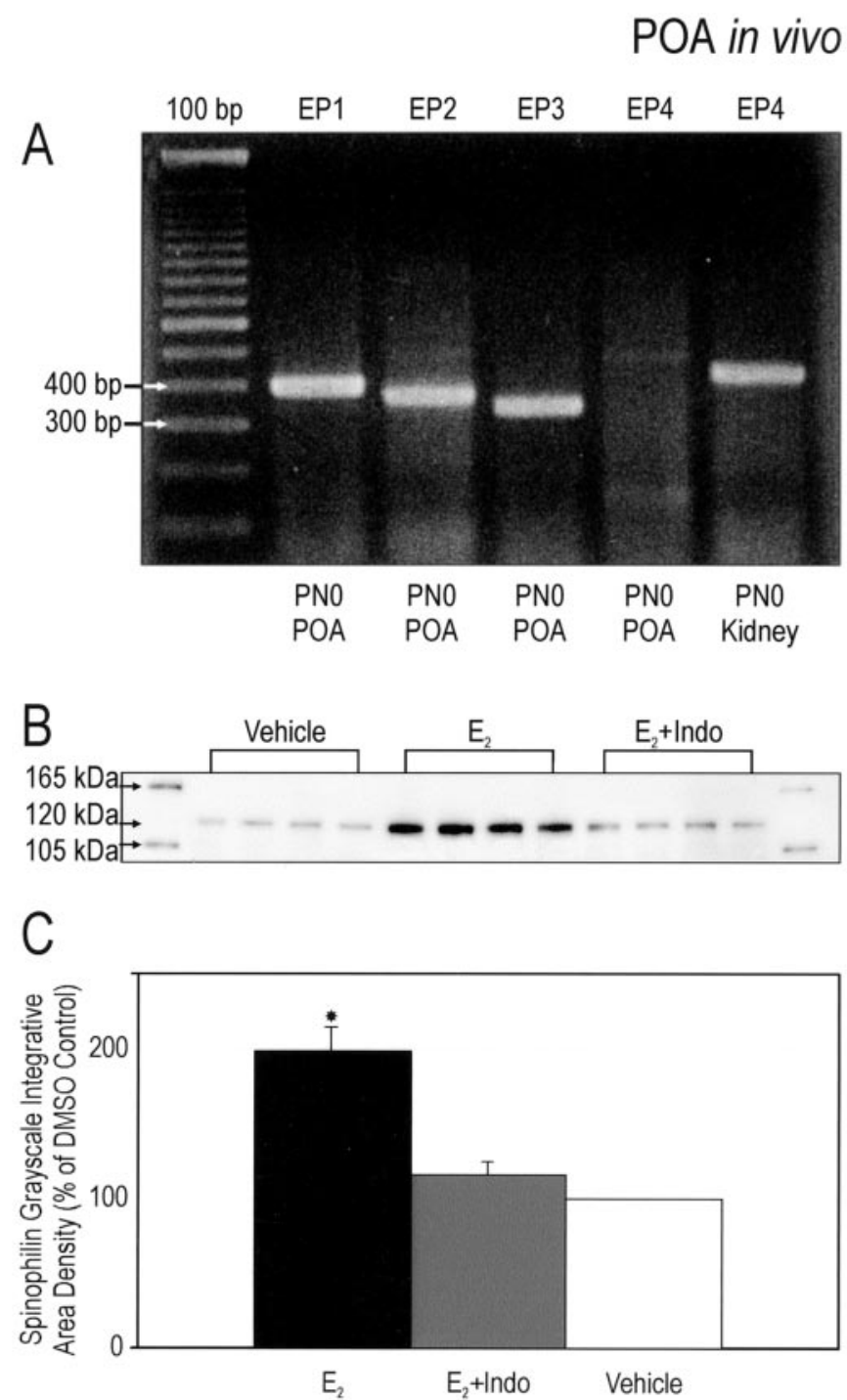

D

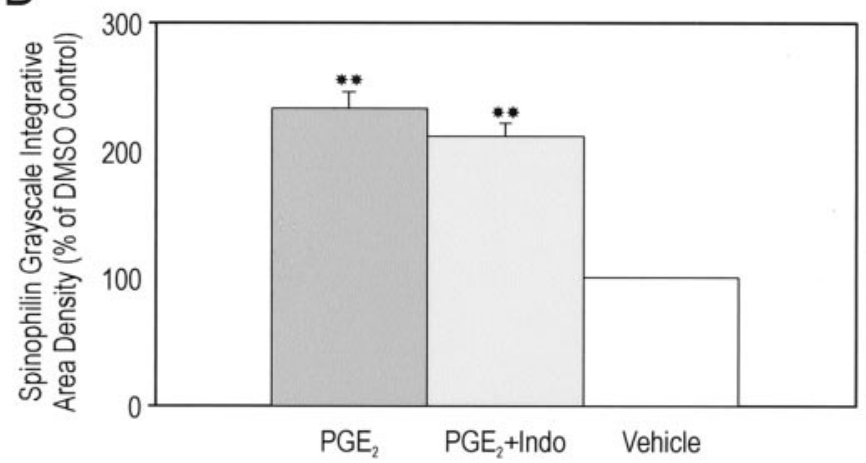

Figure 5. The in vitro effects of $\mathrm{E}_{2}$ and $\mathrm{PGE}_{2}$ on spinophilin expression are maintained in vivo. $A$, The mRNA for three of the four $\mathrm{PGE}_{2}$ receptor (EP1-4) subtypes are detectable within the POA as early as 4 hr postutero. Tissue from rat kidney was used as a positive control for EP4. PNO, Postnatal day 0 . B, Representative Western immunoblot of tissue from the POA collected from animals treated for $48 \mathrm{hr}$ beginning on P0. Animals were exposed to the following either individually or in combination: (1) $0.1 \mathrm{cc}$ sesame oil (subcutaneously), (2) $100 \mu \mathrm{g}$ of $\mathrm{E}_{2}$ in $0.1 \mathrm{cc}$ sesame oil (subcutaneously), (3) $25 \mu \mathrm{g}$ of indomethacin in $0.1 \mathrm{cc}$ sesame oil (subcutaneously), (4) $2 \mu \mathrm{g}$ of $\mathrm{PGE}_{2}$ in $0.1 \mathrm{cc}$ in $0.9 \%$ saline (intracerebroventricularly), or (5) $0.1 \mathrm{cc}$ of $0.9 \%$ saline (intracerebroventricularly). The blot was probed with an anti-spinophilin/neurabin II rabbit polyclonal
23.5; $p=0.001)($ Fig. $5 B, C)$ and $\mathrm{PGE}_{2}\left(F_{(2,9)}=77.6 ; p<0.001\right)$ (Fig. $5 D$ ) in the developing POA as compared with the appropriate controls. In a separate group of animals receiving coadministration of indomethacin $\left(25 \mu \mathrm{g}\right.$, s.c.) with $\mathrm{E}_{2}$ or $\mathrm{PGE}_{2}$, the $\mathrm{E}_{2}$-induced increase in spinophilin expression was fully blocked $(p<0.001)$ (Fig. 5C,D), with no change in the effect of exogenous $\mathrm{PGE}_{2}$.

\section{Estradiol increases $\mathrm{PGE}_{\mathbf{2}}$ levels in the POA}

Coapplication of $\mathrm{E}_{2}$ and $\mathrm{PGE}_{2}$ showed neither an additive nor a synergistic response, further suggesting that these compounds are inducing spine induction through a serial rather than parallel process (although the possibility of a ceiling effect of each compound cannot be ruled out). Coadministration of the prostaglandin synthesis inhibitor indomethacin blocked the effect of $E_{2}$, implying that $\mathrm{PGE}_{2}$ acts downstream of $\mathrm{E}_{2}$. We therefore tested the hypothesis that $\mathrm{E}_{2}$ increases $\mathrm{PGE}_{2}$, while also investigating whether $E_{2}$ promotes the synthesis of the other metabolites of arachidonic acid. We used GC-MS analysis of POA tissue collected from pups $36 \mathrm{hr}$ after being treated immediately postpartum with either $E_{2}$ or vehicle. The homogenate was evaluated for differences in the arachidonic acid metabolites $\mathrm{PGD}_{2}, \mathrm{PGE}_{2}$, $\mathrm{PGF}_{2 \alpha}$, and the two nonenzymatic byproducts of prostacyclin $\left(\mathrm{PGI}_{2}\right)$, and thromboxane- $\mathrm{A}_{2}\left(\mathrm{TXA}_{2}\right), 6$-keto-PGF $\mathrm{PG}_{1 \alpha}$ and $\mathrm{TXB}_{2}$, respectively. Of the lipids analyzed, only $\mathrm{PGE}_{2}$ showed a significant difference $(p<0.002)$ with a threefold increase from $\sim 70$ $\mathrm{pg} / \mathrm{mg}$ of protein to $\sim 280 \mathrm{pg} / \mathrm{mg}$ of protein after exposure to $\mathrm{E}_{2}$ (Fig. 6). Two of the five control animals had $\mathrm{PGE}_{2}$ levels so low as to be undetectable above background and were scored as zero. Whereas $\mathrm{PGD}_{2}, \mathrm{PGF}_{2 \alpha}$, and 6-keto- $\mathrm{PGF}_{1 \alpha}$ levels were significantly greater than that of $\mathrm{PGE}_{2}$, no differences were found between treatment groups. $\mathrm{TXB}_{2}$ levels were undetectable above background (data not shown) in both groups.

\section{Estradiol, but not $\mathrm{PGE}_{2}$, increases spinophilin in the rostral hippocampal formation}

Dendritic spine density is markedly increased on the pyramidal neurons of the adult hippocampus after $E_{2}$ exposure (Woolley et al., 1990; Woolley and McEwen, 1992; Woolley, 1998), but this potential has not been investigated in immature hippocampal neurons. We therefore explored the possible involvement of both $\mathrm{E}_{2}$ and $\mathrm{PGE}_{2}$ in the induction of spines in developing hippocampus. The rostral portion of the perinatal hippocampus was plated and allowed to acclimate for $24 \mathrm{hr}$ before exposure to either $\mathrm{E}_{2}$ or $\mathrm{PGE}_{2}$ for $48 \mathrm{hr}$. As compared with vehicle-treated cells, $\mathrm{E}_{2}$ but not $\mathrm{PGE}_{2}$ induced a significant increase in spinophilin expression $\left(F_{(2,9)}=58.5 ; p<0.001\right)$ (Fig. $\left.7 A, B\right) . \mathrm{E}_{2}$ also induced a significant increase in spinophilin expression in vivo as compared with control tissue $\left(F_{(2,9)}=66.9 ; p<0.001\right)$ (Fig. $\left.7 C\right)$. Unlike our observations in the POA, however, coadministration of indomethacin with $\mathrm{E}_{2}$ did not inhibit this increase. Furthermore, neither $\mathrm{PGE}_{2}$ alone nor $\mathrm{PGE}_{2}$ coapplied with indomethacin had any effect on spinophilin expression in hippocampal neurons (Fig. 7D).

\section{$\leftarrow$}

antibody that recognized an appropriate band at $120 \mathrm{kDa}$. C, D, Quantification of Western immunoblots of preoptic area tissue treated for $48 \mathrm{hr}$ in vivo. Each analysis represents one immunoblot quantified as a ratio of iad to that of controls of the same gel ( $n=4$ per group). Treatment with $\mathrm{E}_{2}$ or $\mathrm{PGE}_{2}$ resulted in a significant increase in levels of spinophilin. Indomethacin blocked the estradiol-induced effect on spinophilin, whereas its coapplication with $\mathrm{PGE}_{2}$ had no effect (ANOVAs; ${ }^{*} p<0.001$ compared with $\mathrm{E}_{2}$ + Indo and vehicle; $* * p 0.001$ compared with vehicle) 


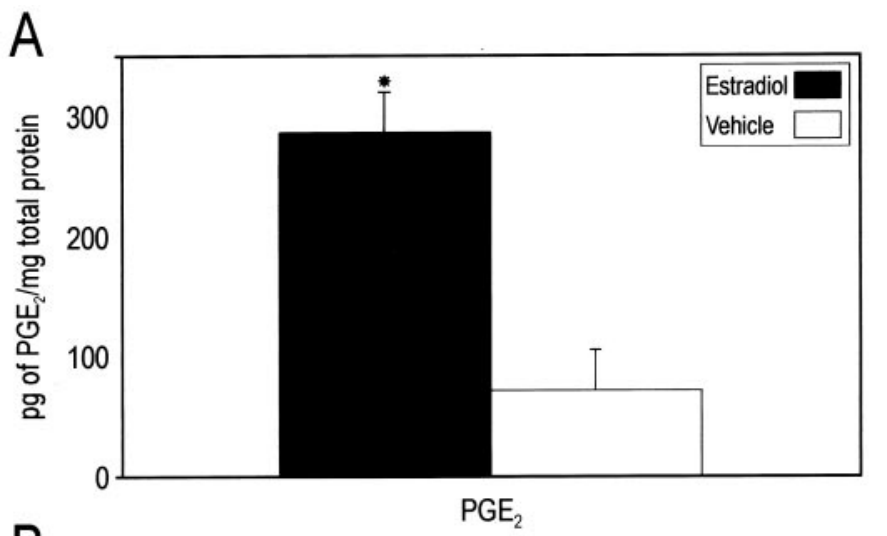

B
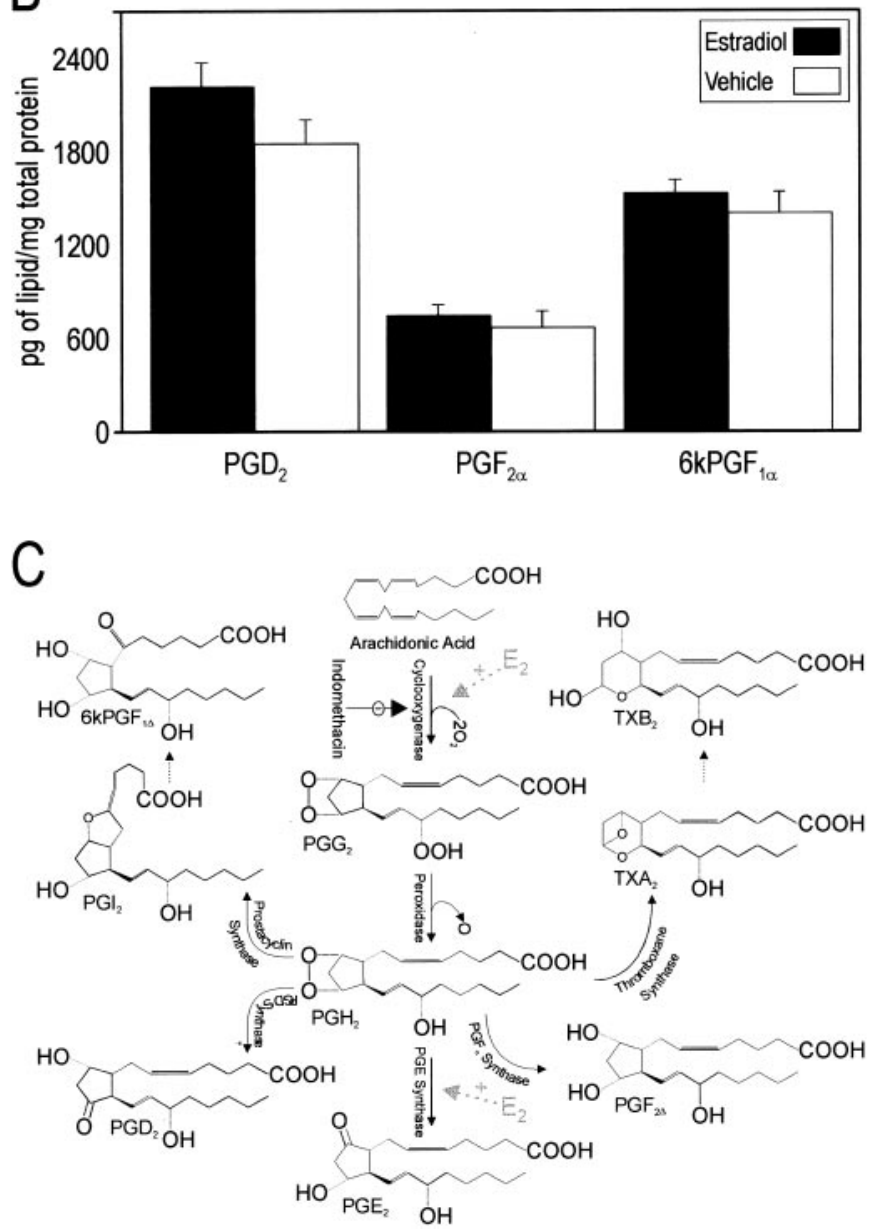

Figure 6. $\mathrm{E}_{2}$ increases $\mathrm{PGE}_{2}$ levels in the developing preoptic area. Quantitative GC-MS analysis was used to measure the levels of various prostanoids and their metabolites in the preoptic area of newborn female rats treated with $\mathrm{E}_{2}$ or vehicle for $36 \mathrm{hr} . A, \mathrm{PGE}_{2}$ levels were increased threefold in rats treated with $100 \mu \mathrm{g}$ of $\mathrm{E}_{2}$ in $0.1 \mathrm{cc}$ sesame oil (subcutaneously) $\left(t\right.$ test, $\left.{ }^{*} p<0.002\right)$. $B$, There was no change in $\mathrm{PGD}_{2}, \mathrm{PGF}_{2 \alpha}$, or 6-keto-PGF $\mathrm{PG}_{1 \alpha}$. $\mathrm{TXB}_{2}$ was undetectable above background. $C$, The pathway of arachidonic acid conversion to the prostanoids via cyclooxygenase suggests the effects of $E_{2}$ may be acting directly at PGE synthase or indirectly via COX-2.

\section{Males exhibit greater spinophilin protein levels on the day of birth in the POA}

To investigate the possibility of a sexually dimorphic expression of spinophilin in the developing POA, tissue was collected within
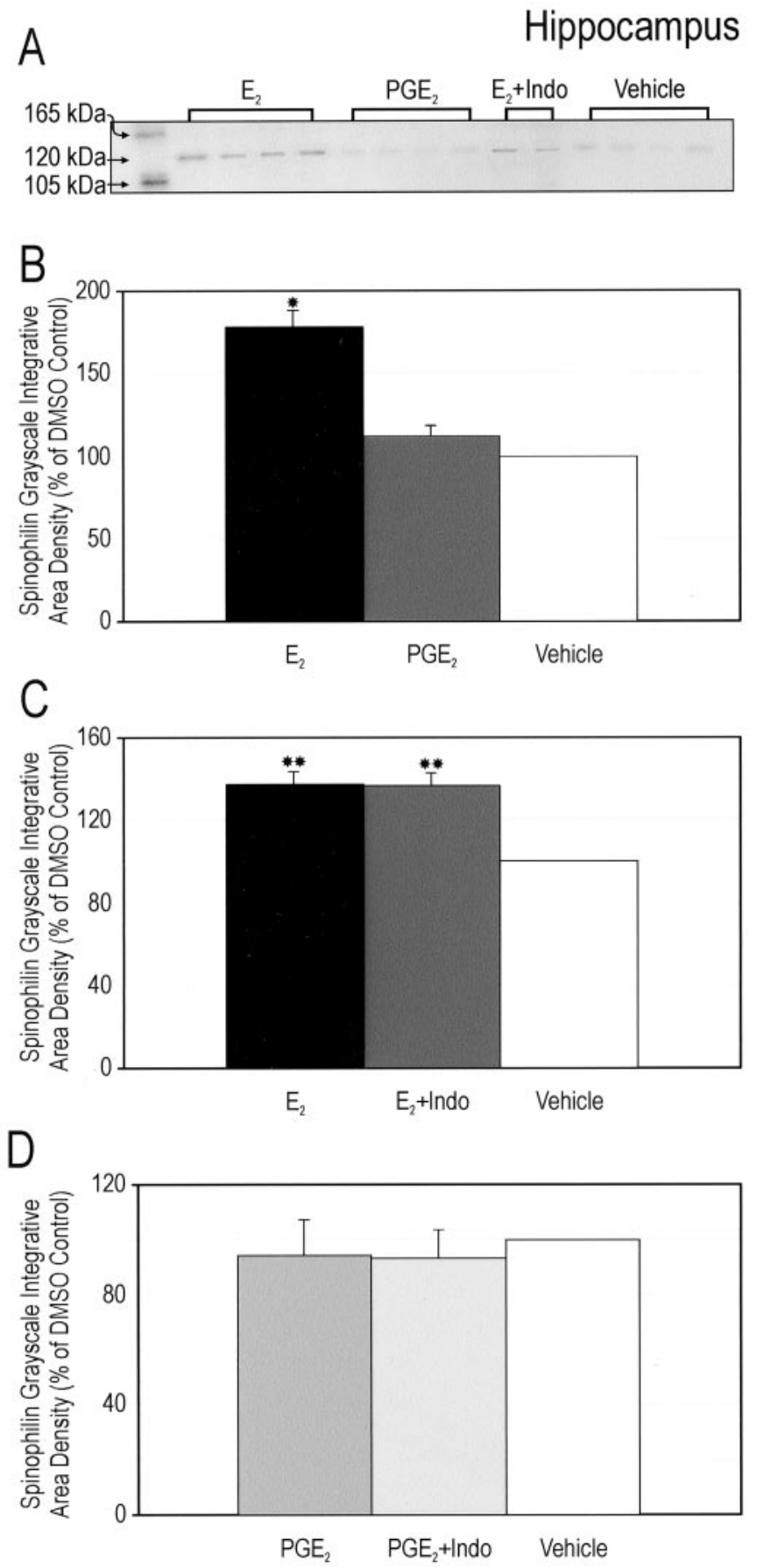

Figure 7. Different mechanisms appear involved in the regulation of spinophilin protein in hippocampal tissue. $A$, Representative Western immunoblot of tissue from the POA collected from animals treated for 48 $\mathrm{hr}$ beginning on P0. Animals were exposed to the following either individually or in combination: (1) $0.1 \mathrm{cc}$ sesame oil (subcutaneously), (2) 100 $\mu \mathrm{g}$ of $\mathrm{E}_{2}$ in $0.1 \mathrm{cc}$ sesame oil (subcutaneously), (3) $25 \mu \mathrm{g}$ of indomethacin in $0.1 \mathrm{cc}$ sesame oil (subcutaneously), (4) $2 \mu \mathrm{g}$ of $\mathrm{PGE}_{2}$ in $0.1 \mathrm{cc}$ in $0.9 \%$ saline (intracerebroventricularly), or (5) $0.1 \mathrm{cc}$ of $0.9 \%$ saline (intracerebroventricularly). The blot was probed with an anti-spinophilin/neurabin II rabbit polyclonal antibody that recognized an appropriate band at 120 $\mathrm{kDa}$. $B$, Analysis of Western immunoblots from cultured newborn rostral hippocampal tissue treated for $48 \mathrm{hr}$ in vitro. The analysis represents one immunoblot quantified as a ratio of iad to that of controls of the same gel ( $n=4$ per group). Treatment with $\mathrm{E}_{2}(5 \mathrm{nM})$ but not $\mathrm{PGE}_{2}(0.5 \mathrm{nM})$ resulted in a significant increase in expression of spinophilin (ANOVA; ${ }^{*} p<0.001$ compared with $\mathrm{PGE}_{2}$ or vehicle). $C, D$, Quantification of Western immunoblots from animals treated $48 \mathrm{hr}$ (Figure legend continues.) 


\section{POA in vivo}
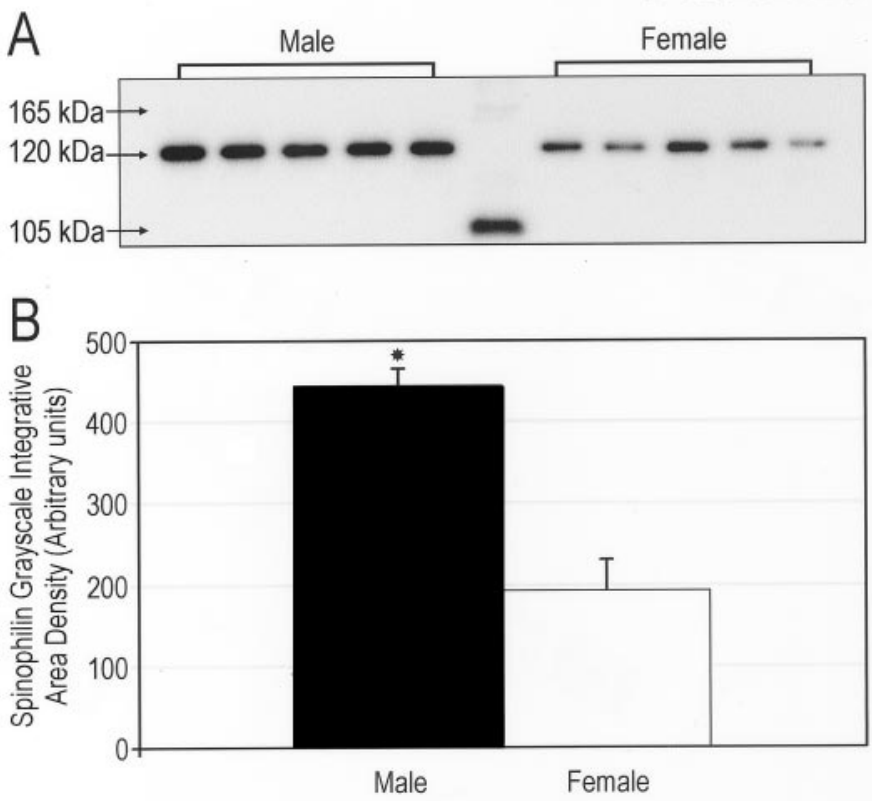

Figure 8. Sexually dimorphic expression of spinophilin on the day of birth in the POA. A, Western immunoblot of preoptic area tissue collected from males and females on the day of birth. The blot was probed with an anti-spinophilin/neurabin II rabbit polyclonal antibody that recognized an appropriate band at $120 \mathrm{kDa}$. B, Quantification of the above Western immunoblot of male and female preoptic area tissue. We determined iad for each band in arbitrary units, and males were compared to females on the same gel $(n=5 /$ group $)$. Males displayed two and a half times the level of spinophilin protein in the POA as compared with that of females $(t$ test, $* p<0.001)$. The magnitude of difference is consistent with the effects on spinophilin levels induced by estradiol or $\mathrm{PGE}_{2}$ treatment both in vivo and in vitro.

$2 \mathrm{hr}$ of birth from male and female littermates and analyzed by Western blot. Males had two and a half times the level of spinophilin protein in the POA as that of females ( $t$ test, $p<$ 0.001) (Fig. 8). The magnitude of this sex difference is consistent with the effects on spinophilin levels induced by estradiol and $\mathrm{PGE}_{2}$ treatment both in vivo and in vitro and suggests that the naturally occurring sex difference in spinophilin is the result of higher endogenous estradiol in the newborn male POA.

\section{DISCUSSION}

We report here a novel mechanism for induction of dendritic spines completely dependent on $\mathrm{E}_{2}$-induced increases in the prostanoid, $\mathrm{PGE}_{2}$, and subsequent glutamatergic activation of AMPA-kainate receptors. Cultured POA neurons exposed to either $E_{2}$ or $P_{G E}$ exhibited an almost threefold rise in the number and density of spine-like processes. The effects of $\mathrm{E}_{2}$ were blocked by the prostanoid synthesis inhibitor, indomethacin, and the combination of $E_{2}$ and $\mathrm{PGE}_{2}$ was equally effective as either one alone. The related but distinct prostaglandin, $\mathrm{PGF}_{2 \alpha}$, had no

\section{$\leftarrow$}

(Figure legend continued.) in vivo as described in $A$. Each analysis represents one immunoblot quantified as a ratio of iad to that of controls of the same gel ( $n=4$ per group). Treatment with $\mathrm{E}_{2}$ alone or in combination with indomethacin resulted in a significant increase in expression of spinophilin. $\mathrm{PGE}_{2}$ alone or in combination with indomethacin had no effect on spinophilin expression (ANOVA; ${ }^{*} p<0.001$ compared with vehicle). effect on spine-like processes of cultured preoptic neurons. Using spinophilin as a marker for spines in vivo, we found parallel responses to those seen in vitro. Although a ceiling effect cannot be ruled out, coapplication of $\mathrm{E}_{2}$ and $\mathrm{PGE}_{2}$ showed neither an additive nor a synergistic response, suggesting that these compounds are acting through a serial rather than parallel process. Quantitative GC-MS analysis demonstrated a threefold increase in the levels of $\mathrm{PGE}_{2}$ within the POA of neonates exposed to $\mathrm{E}_{2}$ as compared with vehicle-treated controls. There was no change in the levels of the other prostanoids, suggesting the effect of $E_{2}$ is specific to $\mathrm{PGE}_{2}$. A comparison of spinophilin between the sexes found neonate males to express 2.5 -fold greater levels than that of neonate females in the perinatal POA, a difference similar in magnitude to that induced by estrogen treatment of females. Glutamatergic activation of AMPA-kainate receptors significantly increased spinophilin expression, and antagonism of these receptors significantly reduced both the $\mathrm{E}_{2}$ and $\mathrm{PGE}_{2}$-induced increases in protein expression. Finally, the ability of $E_{2}$ to induce spinophilin was also observed in hippocampal neurons, however these effects appear to be mediated through a mechanism not involving $\mathrm{PGE}_{2}$.

In rodents, the newborn brain is essentially bipotential, equally capable of becoming masculinized or feminized. Resolution of the ultimate phenotype is a function of the hormonal milieu established by the gonads. In males, the neonatal testes secrete a copious quantity of testosterone during a restricted perinatal developmental window. This testosterone gains access to the brain where it is converted locally to $\mathrm{E}_{2}$ by neuronal aromatase (Naftolin et al., 1971; Ryan et al., 1972; MacLusky and Naftolin, 1981). As a result, local levels of $\mathrm{E}_{2}$ in the developing hypothalamus can be as high as $5 \mathrm{ng} / \mathrm{gm}$ brain tissue (Rhoda et al., 1984). Estradiol induces permanent effects on the developing neuronal substrate, most notably the establishment of sexually dimorphic synaptic patterning. The frequency of dendritic spine synapses can be twice as high in some regions of the male brain compared with that of the female, and yet be the exact opposite in an adjacent region (Matsumoto and Arai, 1980, 1986; Pozzo Miller and Aoki, 1991; Mong et al., 1999, 2001). Despite the fundamental significance of the establishment of sexually dimorphic synaptic profiles, the mechanism or mechanisms by which $E_{2}$ achieves this end has remained virtually unknown.

The POA, a subdivision of the hypothalamus, is centrally involved in the control of sex-typic reproductive behavior, including sexual and maternal behaviors (Meisel and Sachs, 1994; Numan, 1994). Sex differences in morphometry of this brain region include volumetric variance in particular nuclei (Bloch and Gorski, 1988) and synaptic patterning (Raisman and Field, 1973; Larriva-Sahd, 1991). Estrogen receptors are highly expressed by preoptic neurons throughout life (Fuxe et al., 1987; DonCarlos and Handa, 1994; DonCarlos, 1996), and synaptic patterns of the adult brain are established by the neonatal hormonal profile (Raisman and Field, 1973), although additional plasticity is found in the female at puberty (Anderson, 1982). Although we have demonstrated a role for prostaglandins in establishing the neuroarchitecture of the developing brain, it is clear the adult POA remains responsive to $\mathrm{PGE}_{2}$ and may involve a recapitulation of developmental processes. Sexually unresponsive males can be induced to copulate after POA infusions of $\mathrm{PGE}_{2}$ (Clemens and Gladue, 1977), and prostaglandins within the POA are critically involved in control of body temperature (Adair, 1977; Gordon and Heath, 1980).

A critical but limiting variable in studies of synaptic patterning 
is the ability to quantify synapses. Traditional and reliable methods include Golgi impregnation, which allows for analysis of overall cell morphology but not the presence of synapses, and electron microscopy, which allows for the latter but not the former. Although highly informative, both of these techniques are labor intensive and can become prohibitive when multiple manipulations are compared. Spinophilin was used here as an indirect marker for spines. Spinophilin localizes to the head and neck region of dendritic spines and interacts with several proteins, including actin (Stephens and Banting, 2000). Actin is central to the formation, maintenance, morphology, and activity of spines (Fifkova, 1985; Matus, 2000; Kaech et al., 2001), and spinophilin bundles actin filaments, suggesting a role as one of the organizers of the actin-based cytoskeleton in dendritic spines (Nakanishi et al., 1997; Feng et al., 2000; Stephens and Banting, 2000). Such properties make spinophilin not only a marker of dendritic spine density, but also suggest it may be a mediator of dynamic changes in spine morphology. Others have also observed a comparable relationship between the magnitude of synapse-related proteins and changes in spinophilin (Brake et al., 2001), suggesting that this biomarker is a valuable tool for assaying changes in synaptic profiling under a myriad of conditions. In the hippocampus we detected a $30 \%$ increase in spinophilin expression in response to $\mathrm{E}_{2}$, a result consistent in both scale and direction with previous studies investigating the effects of $\mathrm{E}_{2}$ on hippocampal spines and spine synapses (Woolley et al., 1990; Woolley and McEwen, 1992; Woolley, 1998). Although extremely powerful, using spinophilin as a marker of dendritic spines does have its limitations. Analyses of protein levels cannot discern if a treatment selectively promotes the construction of some spines versus the dismantling of others. Furthermore, assays for spinophilin do not reveal information regarding the status of spine function or activity. Nonetheless, the striking correlation we observed in the effects of treatment on spine-like processes and spinophilin levels measured by Western blot both in vivo and in vitro suggest this protein is a reliable predictor of spine density.

A link between glutamate receptor activation, which initiates most changes in synaptic strength, and subsequent modifications of dendritic density has been difficult to establish in the vertebrate CNS. Combined electrophysiologic and morphometric analyses have demonstrated the necessity of AMPA receptor activation in the maintenance and structure of postsynaptic dendritic spines (McKinney et al., 1999a,b). NMDA receptor activation, on the other hand, appears critical to synaptogenesis and the pruning of dendritic spines (Luthi et al., 2001). Although our investigations do not explore synaptogenesis per se, they do demonstrate that AMPA-kainate receptor activation is critical and sufficient to increase a dendritic protein, spinophilin, within the developing POA in response to estradiol exposure. Of great interest is the finding that AMPA-kainate-specific antagonists alone had no effect on baseline spinophilin expression, suggesting that in the POA, glutamatergic activation of these receptors are not involved in maintenance, but rather creation of dendritic spines.

A central question raised by the current findings is whether $\mathrm{E}_{2}$-induced increases in $\mathrm{PGE}_{2}$ are manifest in POA neurons, astrocytes, or a combination of the two. Although it is clear that neurons of the POA express significant concentrations of estrogen receptor throughout life (Fuxe et al., 1987; Yuri and Kawata, 1991; DonCarlos, 1996), there is ambiguity regarding the potential for the same receptors in astrocytes of the POA (Langub and Watson, 1992; Ojeda and Ma, 1999). Similarly, there is uncertainty regarding whether $\mathrm{COX}-2$ is exclusively neuronal or also present in astrocytes under restricted conditions (Kaufmann et al., 1996; O'Banion et al., 1996). Given that the preponderance of evidence suggests neuronal localization for both the estrogen receptor and COX-2, we have developed a working model in which $E_{2}$ increases $P_{G} E_{2}$ in neurons which then diff uses to act on neighboring astrocytes. Evidence suggests that neighboring astrocytes respond to $\mathrm{PGE}_{2}$ by releasing glutamate (Nicol et al., 1992; Bezzi et al., 1998), which in our model back-communicates to trigger neuronal AMPA-kainate receptors, activation of which has been implicated in dendritic spine modification (McKinney et al., 1999a; Goldin et al., 2001; Luthi et al., 2001). Several components of this model remain to be tested.

Our data suggest a regionally specific effect of $E_{2}$ in the POA involving the synthesis of $\mathrm{PGE}_{2}$ because this mechanism was not evident in the developing hippocampus. Interestingly, outside of the cortex, the densest collection of COX-2-expressing neurons is found in the POA, with only a few in the CA1 field of the hippocampus (Breder et al., 1995). Regional differences in either the receptors or synthetic enzymes for $\mathrm{PGE}_{2}$ may underlie the specificity of the effects of $\mathrm{PGE}_{2}$. The localization of COX-2 to dendritic spines and its rapid induction with synaptic activity previously led to the hypothesis that this immediate early gene is a modulator of neuronal plasticity (Kaufmann et al., 1997). The observation that pharmacological inhibition of COX-2 does not result in disturbances in learning and memory seemed to contradict this view (Kaufmann et al., 1997). Our findings may shed light on this discrepancy. Estradiol-induced increases in hippocampal dendritic spine density have been correlated with enhanced NMDA-mediated currents (Woolley and McEwen, 1994; Woolley et al., 1997) and exaggerated LTP (Warren et al., 1995; Cordoba Montoya and Carrer, 1997; Gupta et al., 2001), a cellular correlate of learning and memory. Performance on various hippocampal-dependent spatial tasks are enhanced by estradiol pretreatment, and the increase in dendritic spines induced by estradiol has been directly correlated with enhanced performance (Sandstrom and Williams, 2001). In contrast, $\mathrm{E}_{2}$ induction of dendritic spines in the POA is likely related to sex differences in reproductive behavior and would be predicted to have no effect on learning and memory. This divergence in the mechanism of $\mathrm{E}_{2}$-mediated neuronal plasticity demonstrates how epigenetic control of behavior is achieved through regionally specific signal transduction pathways.

\section{REFERENCES}

Adair ER (1977) Skin, preoptic, and core temperatures influence behavioral thermoregulation. J Appl Physiol 42:559-564.

Allen PB, Ouimet CC, Greengard P (1997) Spinophilin, a novel protein phosphatase 1 binding protein localized to dendritic spines. Proc Natl Acad Sci USA 941:9956-9961.

Altman J, Bayer SA (1995) Atlas of prenatal rat brain development. Boca Raton, FL: CRC.

Anderson CH (1982) Changes in dendritic spine density in the preoptic area of the female rat at puberty. Brain Res Bull 8:261-265.

Baloyannis SJ, Kim SU (1979) Experimental modification of cerebellar development in tissue culture: $x$-irradiation induces granular degeneration and unattached Purkinje cell dendritic spines. Neurosci Lett 12:283-288

Bezzi P, Carmignoto G, Pasti L, Vesce S, Rossi D, Rizzini BL, Pozzan T, Volterra A (1998) Prostaglandins stimulate calcium-dependent glutamate release in astrocytes. Nature 391:281-285.

Bloch GJ, Gorski RA (1988) Estrogen/progesterone treatment in adulthood affects the size of several components of the medial preoptic area in the male rat. J Comp Neurol 4:613-622.

Brake WG, Alves SE, Dunlop JC, Lee SJ, Bulloch K, Allen PB, Greengard P, McEwen BS (2001) Novel target sites for estrogen action in the dorsal hippocampus: an examination of synaptic proteins. Endocrinology 142:1284-1289.

Breder CD, Dewitt D, Kraig RP (1995) Characterization of inducible cyclooxygenase in rat brain. J Comp Neurol 355:296-315. 
Caggiano AO, Kraig RP (1998) Prostaglandin E2 and 4-aminopyridine prevent the lipopolysaccharide- induced outwardly rectifying potassium current and interleukin-1beta production in cultured rat microglia. J Neurochem 70:2357-2368.

Calizo LH, Flanagan-Cato LM (2000) Estrogen selectively regulates spine density within the dendritic arbor of rat ventromedial hypothalamic neurons. J Neurosci 20:1589-1596.

Clemens LG, Gladue BA (1977) Effect of prostaglandin E2 on masculine sexual behaviour in the rat. J Endocrinol 75:383-389.

Colonnier M (1968) Synaptic patterns on different cell types in the different laminae of the cat visual cortex. An electron microscope study. Brain Res 9:268-287.

Cordoba Montoya DA, Carrer HF (1997) Estrogen facilitates induction of long term potentiation in the hippocampus of awake rats. Brain Res 778:430-438.

DonCarlos LL (1996) Developmental profile and regulation of estrogen receptor (ER) mRNA expression in the preoptic area of prenatal rats. Brain Res Dev Brain Res 94:224-233.

DonCarlos LL, Handa RJ (1994) Developmental profile of estrogen receptor mRNA in the preoptic area of male and female neonatal rats. Brain Res Dev Brain Res 79:283-289.

Feng J, Yan Z, Ferreira A, Tomizawa K, Liauw JA, Zhuo M, Allen PB, Ouimet CC, Greengard P (2000) Spinophilin regulates the formation and function of dendritic spines. Proc Natl Acad Sci USA 97:92879292.

Fifkova E (1985) A possible mechanism of morphometric changes in dendritic spines induced by stimulation. Cell Mol Neurobiol 5:47-63.

Fuxe K, Cintra A, Agnati LF, Harfstrand A, Wikstrom AC, Okret S, Zoli M, Miller LS, Greene JL, Gustafsson JA (1987) Studies on the cellular localization and distribution of glucocorticoid receptor and estrogen receptor immunoreactivity in the central nervous system of the rat and their relationship to the monoaminergic and peptidergic neurons of the brain. J Steroid Biochem 27:159-170.

Goldin M, Segal M, Avignone E (2001) Functional plasticity triggers formation and pruning of dendritic spines in cultured hippocampal networks. J Neurosci 21:186-193.

Gordon CJ, Heath JE (1980) Effects of prostaglandin E2 on the activity of thermosensitive and insensitive single units in the preoptic/anterior hypothalamus of unanesthetized rabbits. Brain Res 183:113-121.

Gupta RR, Sen S, Diepenhorst LL, Rudick CN, Maren S (2001) Estrogen modulates sexually dimorphic contextual fear conditioning and hippocampal long-term potentiation (LTP) in rats(1). Brain Res 888: $356-365$.

Herrmann K (1996) Differential distribution of AMPA receptors and glutamate during pre- and postnatal development in the visual cortex of ferrets. J Comp Neurol 375:1-17.

Ito S, Okuda-Ashitaka E, Minami T (2001) Central and peripheral roles of prostaglandins in pain and their interactions with novel neuropeptides nociceptin and nocistatin. Neurosci Res 41:299-332.

Kaech S, Parmar H, Roelandse M, Bornmann C, Matus A (2001) Cytoskeletal microdifferentiation: a mechanism for organizing morphological plasticity in dendrites. Proc Natl Acad Sci USA 98:7086-7092.

Karmali RA, Welt S, Thaler HT, Lefevre F (1983) Prostaglandins in breast cancer: relationship to disease stage and hormone status. $\mathrm{Br} \mathbf{J}$ Cancer 48:689-696.

Katayama S, Lee JB (1985) Estradiol stimulates rat renopapillary prostaglandin E2 (PGE2), but not PGF2 alpha biosynthesis. Endocrinology 117:656-661.

Kaufmann WE, Worley PF, Pegg J, Bremer M, Isakson P (1996) $\mathrm{COX}-2$, a synaptically induced enzyme, is expressed by excitatory neurons at postsynaptic sites in rat cerebral cortex. Proc Natl Acad Sci USA 93:2317-2321.

Kaufmann WE, Andreasson KI, Isakson PC, Worley PF (1997) Cyclooxygenases and the central nervous system. Prostaglandins 54:601624.

Kundu N, Yang Q, Dorsey R, Fulton AM (2001) Increased cyclooxygenase-2 (cox-2) expression and activity in a murine model of metastatic breast cancer. Int J Cancer 93:681-686.

Langub Jr MC, Watson Jr RE (1992) Estrogen receptor-immunoreactive glia, endothelia, and ependyma in guinea pig preoptic area and median eminence: electron microscopy. Endocrinology 130:364-372.

Larkman AU (1991) Dendritic morphology of pyramidal neurones of the visual cortex of the rat: III. Spine distributions. J Comp Neurol 306:332-343.

Larriva-Sahd J (1991) Ultrastructural evidence of a sexual dimorphism in the neuropil of the medial preoptic nucleus of the rat: a quantitative study. Neuroendocrinology 54:416-419.

Luczak A, Szmigielski S, Gumulka SW (1979) Decreased myocardial and renal content of $3^{\prime}, 5^{\prime}$-AMP in genetically hypertensive rats: effects of PGE2 and PGF2 alpha. Pol J Pharmacol Pharm 31:589-594.

Luthi A, Schwyzer L, Mateos JM, Gahwiler BH, McKinney RA (2001) NMDA receptor activation limits the number of synaptic connections during hippocampal development. Nat Neurosci 4:1102-1107.

Ma YJ, Berg-von der Emde K, Rage F, Wetsel WC, Ojeda SR (1997) Hypothalamic astrocytes respond to transforming growth factor-alpha with the secretion of neuroactive substances that stimulate the release of luteinizing hormone-releasing hormone. Endocrinology 138:19-25.

MacLusky NJ, Naftolin F (1981) Sexual differentiation of the central nervous system. Science 2114:1294-1302.

Matsumoto A, Arai Y (1980) Sexual dimorphism in 'wiring pattern' in the hypothalamic arcuate nucleus and its modification by neonatal hormonal environment. Brain Res 190:238-242.

Matsumoto A, Arai Y (1986) Male-female difference in synaptic organization of the ventromedial nucleus of the hypothalamus in the rat Neuroendocrinology 42:232-236.

Matsumoto A, Murakami S, Arai Y (1988) Neurotropic effects of estrogen on the neonatal preoptic area grafted into the adult rat brain. Cell Tissue Res 252:33-37.

Mattson MP (1988) Neurotransmitters in the regulation of neuronal cytoarchitecture. Brain Res 472:179-212.

Matus A (2000) Actin-based plasticity in dendritic spines. Science 290: $754-758$.

McEwen BS, Alves SE (1999) Estrogen actions in the central nervous system. Endocr Rev 20:279-307.

McKinney RA, Capogna M, Durr R, Gahwiler BH, Thompson SM (1999a) Miniature synaptic events maintain dendritic spines via AMPA receptor activation. Nat Neurosci 2:44-49.

McKinney RA, Luthi A, Bandtlow CE, Gahwiler BH, Thompson SM (1999b) Selective glutamate receptor antagonists can induce or prevent axonal sprouting in rat hippocampal slice cultures. Proc Natl Acad Sci USA 96:11631-11636.

Meisel RL, Sachs BD (1994) The physiology of male sexual behavior. In: The physiology of reproduction, Vol 2 (Knobil E, Neill JD), pp 3-107. New York: Raven.

Meshul CK, Seil FJ (1988) Transplanted astrocytes reduce synaptic density in the neuropil of cerebellar cultures. Brain Res 441:23-32.

Mong JA, Glaser E, McCarthy MM (1999) Gonadal steroids promote glial differentiation and alter neuronal morphology in the developing hypothalamus in a regionally specific manner. J Neurosci 19:1464-1472.

Mong JA, Roberts RC, Kelly JJ, McCarthy MM (2001) Gonadal steroids reduce the density of axospinous synapses in the developing rat arcuate nucleus: an electron microscopy analysis. J Comp Neurol 432:259-267.

Montano MM, Welshons WV, vom Saal FS (1995) Free estradiol in serum and brain uptake of estradiol during fetal and neonatal sexual differentiation in female rats. Biol Reprod 53:1198-1207.

Morimoto A, Long NC, Nakamori T, Murakami N (1991) The effect of prostaglandin E2 on the body temperature of restrained rats. Physiol Behav 50:249-253.

Moser MB, Trommald M, Andersen P (1994) An increase in dendritic spine density on hippocampal CA1 pyramidal cells following spatial learning in adult rats suggests the formation of new synapses. Proc Natl Acad Sci USA 91:12673-12675.

Mouihate A, Lestage J (1995) Estrogen increases the release of epidermal growth factor from individual pituitary cells in female rats. J Endocrinol 146:495-500.

Munoz-Cueto JA, Garcia-Segura LM, Ruiz-Marcos A (1991) Regional sex differences in spine density along the apical shaft of visual cortex pyramids during postnatal development. Brain Res 540:41-47.

Murphy DD, Segal M (1996) Regulation of dendritic spine density in cultured rat hippocampal neurons by steroid hormones. J Neurosci 16:4059-4068

Naftolin F, Ryan KJ, Petro Z (1971) Aromatization of androstenedione by the diencephalon. J Clin Endocrinol Metab 33:368-370.

Nakanishi H, Obaishi H, Satoh A, Wada M, Mandai K, Satoh K, Nishioka H, Matsuura Y, Mizoguchi A, Takai Y (1997) Neurabin: a novel neural tissue-specific actin filament-binding protein involved in neurite formation. J Cell Biol 139:951-961.

Nicol GD, Klingberg DK, Vasko MR (1992) Prostaglandin E2 increases calcium conductance and stimulates release of substance $\mathrm{P}$ in avian sensory neurons. J Neurosci 12:1917-1927.

Numan M (1994) Maternal behavior. In: The physiology of reproduction, Vol 2 (Knobil E, Neill JD), pp 221-302. New York: Raven.

O'Banion MK, Miller JC, Chang JW, Kaplan MD, Coleman PD (1996) Interleukin-1 beta induces prostaglandin $\mathrm{G} / \mathrm{H}$ synthase-2 (cyclooxygenase-2) in primary murine astrocyte cultures. J Neurochem 66:2532-2540.

Ojeda SR, Ma YJ (1999) Glial-neuronal interactions in the neuroendocrine control of mammalian puberty: facilitatory effects of gonadal steroids. J Neurobiol 40:528-540.

Perez J, Naftolin F, Garcia Segura LM (1990) Sexual differentiation of synaptic connectivity and neuronal plasma membrane in the arcuate nucleus of the rat hypothalamus. Brain Res 527:116-122.

Pfrieger FW, Barres BA (1997) Synaptic efficacy enhanced by glial cells in vitro. Science 277:1684-1687.

Pozzo Miller LD, Aoki A (1991) Stereological analysis of the hypothalamic ventromedial nucleus. II. Hormone-induced changes in the synaptogenic pattern. Brain Res Dev Brain Res 61:189-196.

Rage F, Lee BJ, Ma YJ, Ojeda SR (1997) Estradiol enhances prostaglandin E2 receptor gene expression in luteinizing hormone-releasing hormone $(\mathrm{LHRH})$ neurons and facilitates the LHRH response to 
PGE2 by activating a glia-to-neuron signaling pathway. J Neurosci 17:9145-9156.

Raisman G, Field PM (1973) Sexual dimorphism in the neuropil of the preoptic area of the rat and its dependence on neonatal androgen. Brain Res 54:1-29.

Rhoda J, Corbier P, Roffi J (1984) Gonadal steroid concentrations in serum and hypothalamus of the rat at birth: aromatization of testosterone to 17 beta-estradiol. Endocrinology 114:1754-1760.

Ruwe WD, Myers RD (1979) Fever produced by intrahypothalamic pyrogen: effect of protein synthesis inhibition by anisomycin. Brain Res Bull 4:741-745.

Ryan KJ, Naftolin F, Reddy V, Flores F, Petro Z (1972) Estrogen formation in the brain. Am J Obstet Gynecol 114:454-460.

Sandstrom NJ, Williams CL (2001) Memory retention is modulated by acute estradiol and progesterone replacement. Behav Neurosci 115: 384-393

Sanzgiri RP, Araque A, Haydon PG (1999) Prostaglandin E(2) stimulates glutamate receptor-dependent astrocyte neuromodulation in cultured hippocampal cells. J Neurobiol 41:221-229.

Seil FJ (1997) Cerebellar culture models of dendritic spine proliferation after transplantation of glia. J Neural Transplant Plast 6:1-10.

Seil FJ, Eckenstein FP, Reier PJ (1992) Induction of dendritic spine proliferation by an astrocyte secreted factor. Exp Neurol 117:85-89.

Sorra KE, Harris KM (2000) Overview on the structure, composition, function, development, and plasticity of hippocampal dendritic spines. Hippocampus 10:501-511.

Southall MD, Vasko MR (2000) Prostaglandin E(2)-mediated sensitization of rat sensory neurons is not altered by nerve growth factor. Neurosci Lett 287:33-36.

Stephens DJ, Banting G (2000) In vivo dynamics of the F-actin-binding protein neurabin-II. Biochem J 345:185-194.

Takadera T, Yumoto H, Tozuka Y, Ohyashiki T (2002) Prostaglandin $\mathrm{E}(2)$ induces caspase-dependent apoptosis in rat cortical cells. Neurosci Lett 317:61-64.
Tremblay E, Roisin MP, Represa A, Charriaut-Marlangue C, Ben-Ari Y (1988) Transient increased density of NMDA binding sites in the developing rat hippocampus. Brain Res 461:393-396.

Ullian EM, Sapperstein SK, Christopherson KS, Barres BA (2001) Control of synapse number by glia. Science 291:657-661.

Villani F, Chiarra A, Cristalli S, Piccinini F (1974) Effect of PGE2 on the turnover of calcium in rat uterus. Experientia 30:532-534.

Warren SG, Humphreys AG, Juraska JM, Greenough WT (1995) LTP varies across the estrous cycle: enhanced synaptic plasticity in proestrus rats. Brain Res 703:26-30.

Whalen RE, Nadler RD (1963) Suppression of the development of female behavior by estrogen administered in infancy. Science 141:273274.

Woolley CS (1998) Estrogen-mediated structural and functional synaptic plasticity in the female rat hippocampus. Horm Behav 34:140-148

Woolley CS, McEwen BS (1992) Estradiol mediates fluctuation in hippocampal synapse density during the estrous cycle in the adult rat J Neurosci 12:2549-2554.

Woolley CS, McEwen BS (1994) Estradiol regulates hippocampal dendritic spine density via an $N$-methyl-D-aspartate receptor-dependent mechanism. J Neurosci 14:7680-7687.

Woolley CS, Gould E, Frankfurt M, McEwen BS (1990) Naturally occurring fluctuation in dendritic spine density on adult hippocampal pyramidal neurons. J Neurosci 10:4035-4039.

Woolley CS, Weiland NG, McEwen BS, Schwartzkroin PA (1997) Estradiol increases the sensitivity of hippocampal CA1 pyramidal cells to NMDA receptor-mediated synaptic input: correlation with dendritic spine density. J Neurosci 17:1848-1859.

Yuri K, Kawata M (1991) The effect of estrogen on the estrogen receptor-immunoreactive cells in the rat medial preoptic nucleus. Brain Res 548:50-54.

Zhang C, Hammassaki-Britto DE, Britto LR, Duvoisin RM (1996) Expression of glutamate receptor subunit genes during development of the mouse retina. NeuroReport 8:335-340. 